\title{
molecules
}

ISSN 1420-3049

www.mdpi.com/journal/molecules

Review

\section{Endocannabinoids, Related Compounds and Their Metabolic Routes}

\author{
Filomena Fezza $^{1,2, *}$, Monica Bari ${ }^{1}$, Rita Florio ${ }^{3}$, Emanuela Talamonti ${ }^{4,5}$, Monica Feole ${ }^{1,2}$ \\ and Mauro Maccarrone ${ }^{2,5, *}$
}

1 Department of Experimental Medicine \& Surgery, Tor Vergata University of Rome, 00133 Rome, Italy; E-Mails: bari@med.uniroma2.it (M.B.); monica.feole@hotmail.it (M.F.)

2 European Center for Brain Research/IRCCS Santa Lucia Foundation, 00143 Rome, Italy

3 Department of Movement, Human and Health Sciences, Foro Italico University of Rome, 00128 Rome, Italy; E-Mail: rit.flo@libero.it

4 Endocannabinoid Research Group, Istituto di Chimica Biomolecolare, Consiglio Nazionale delle Ricerche, 80078 Pozzuoli (NA), Italy; E-Mail: emanuelatalamonti.86@libero.it

5 Center of Integrated Research, Campus Bio-Medico University of Rome, 00135 Rome, Italy

* Authors to whom correspondence should be addressed:

E-Mails: filomena.fezza@uniroma2.it (F.F.); m.maccarrone@unicampus.it (M.M.).

External Editor: Derek J. McPhee

Received: 1 August 2014; in revised form: 16 October 2014 / Accepted: 16 October 2014 /

Published: 24 October 2014

\begin{abstract}
Endocannabinoids are lipid mediators able to bind to and activate cannabinoid receptors, the primary molecular targets responsible for the pharmacological effects of the $\Delta^{9}$-tetrahydrocannabinol. These bioactive lipids belong mainly to two classes of compounds: $N$-acylethanolamines and acylesters, being $N$-arachidonoylethanolamine (AEA) and 2-arachidonoylglycerol (2-AG), respectively, their main representatives. During the last twenty years, an ever growing number of fatty acid derivatives (endocannabinoids and endocannabinoid-like compounds) have been discovered and their activities biological is the subject of intense investigations. Here, the most recent advances, from a therapeutic point of view, on endocannabinoids, related compounds, and their metabolic routes will be reviewed.
\end{abstract}


Keywords: anandamide; 2-arachidonoylglycerol; endocannabinoid metabolic routes; fatty acids

\section{Introduction}

The biological effects of marijuana and $\Delta^{9}$-tetrahydrocannabinol (THC), its major psychoactive component, are mediated by two G protein-coupled receptors (GPCR), type-1 (CB $\mathrm{R})$ and type-2 $\left(\mathrm{CB}_{2} \mathrm{R}\right)$ cannabinoid receptors [1].

The finding of the genes that encode CBRs has led to the quest to discover their endogenous ligands [termed "endocannabinoids (eCBs)"], and the enzymes responsible for eCBs synthesis and degradation, leading in turn to the discovery of an entirely new endogenous signalling system, now known as the "endocannabinoid system (ECS)" [2,3].

In line with the high lipophilicity of THC (Figure 1), all eCBs are obtained from unsaturated fatty acids [4]. The most important of these endogenous ligands are two arachidonic acid (AA)-derivatives: $\mathrm{N}$-arachidonoylethanolamine (anandamide, AEA) [5] and 2-arachidonoylglycerol (2-AG) (Figure 1 and Table 1) [6,7], that belong to the large families of $N$-acylethanolamines (NAEs) and 2-monoacylglycerols (MAG), respectively.

Figure 1. Chemical structures of THC and two prominent endocannabinoids.

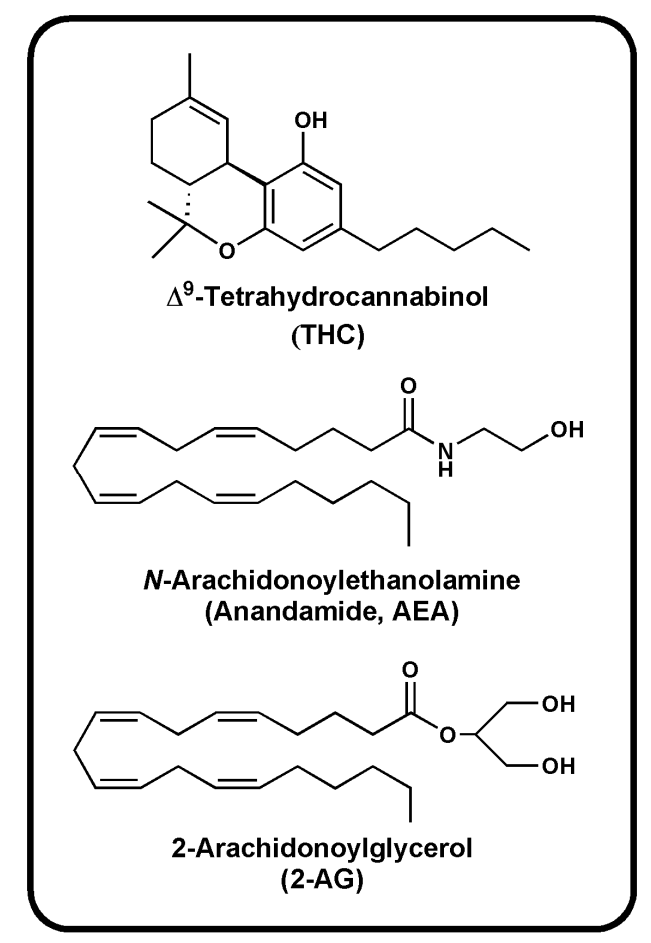


Table 1. eCBs and eCBs-like compounds, their molecular targets, biosynthetic and catabolic enzymes.

\begin{tabular}{|c|c|c|c|}
\hline Bioactive Lipids & $\begin{array}{c}\text { Molecular } \\
\text { Targets }\end{array}$ & $\begin{array}{c}\text { Biosynthetic } \\
\text { Enzymes }\end{array}$ & Catabolic Enzymes \\
\hline \multicolumn{4}{|c|}{ n-6 eCBs derivatives } \\
\hline AEA & $\begin{array}{c}\text { CB1 [1] } \\
\text { CB2 [1] } \\
\text { TRPV1 [8] } \\
\text { PPAR } \alpha \text { [9] } \\
\text { PPAR } \gamma[9] \\
\text { GPR55 [10] }\end{array}$ & $\begin{array}{c}\text { NAT [11] } \\
\text { iNAT [12-14] } \\
\text { NAPE-PLD [15] } \\
\text { ABHD4 [16-18] } \\
\text { Lyso-PLD [16-18] } \\
\text { GDE1[16-18] } \\
\text { PTPN22 [16-18] }\end{array}$ & $\begin{array}{c}\text { FAAH-1 [19] } \\
\text { FAAH-2 [20] } \\
\text { NAAH [21] } \\
\text { LOXx [22] } \\
\text { COX-2 }[23,24] \\
\text { CytP450 [25] }\end{array}$ \\
\hline 2-AG & $\begin{array}{c}\text { CB1 [1] } \\
\text { CB2 [1] } \\
\text { TRPV1 [26] }\end{array}$ & $\begin{array}{c}\text { PLC } \beta[27,28] \\
\text { DAGL } \alpha[29] \\
\text { DAGL } \beta[29]\end{array}$ & $\begin{array}{c}\text { MAGL }[30] \\
\text { FAAH-1[19] } \\
\text { ABHD6 [31,32] } \\
\text { ABHD12 }[31,32] \\
\text { LOXx }[22] \\
\text { COX-2 }[23,24]\end{array}$ \\
\hline NADA & $\begin{array}{c}\text { CB1 [1] } \\
\text { TRPV1 [33] } \\
\text { PPAR } \gamma \text { [34] }\end{array}$ & $\begin{array}{c}\text { Postulate } \\
\text { condensation } \\
\text { between the } \\
\text { catecholamine } \\
\text { with AA }\end{array}$ & $\begin{array}{l}\text { Slow hydrolysis } \\
\text { of the amide bond or } \\
\text { the methylation of } \\
\text { catecholamine }\end{array}$ \\
\hline noladin ether & $\begin{array}{c}\text { CB1 }[35,36] \\
\text { CB2 [35] } \\
\text { GPR55 [37] } \\
\text { PPAR } \alpha[9] \\
\end{array}$ & unknown & unknown \\
\hline virodhamine & $\begin{array}{c}\text { CB1 [38] } \\
\text { CB2 [38] } \\
\text { GPR55 [37] } \\
\text { PPAR } \alpha \text { [9] } \\
\end{array}$ & unknown & unknown \\
\hline & \multicolumn{3}{|c|}{ n-3 eCBs derivatives } \\
\hline DHEA & $\begin{array}{c}\text { CB1 [39] } \\
\text { CB2 [39] } \\
\text { PPAR } \gamma[40]\end{array}$ & $\begin{array}{l}\text { Postulate as } \\
\text { other NAEs }\end{array}$ & $\begin{array}{l}\text { Postulate as } \\
\text { other NAEs }\end{array}$ \\
\hline EPEA & $\begin{array}{c}\text { CB1 [39] } \\
\text { CB2 [39] } \\
\text { PPAR } \gamma[41]\end{array}$ & $\begin{array}{l}\text { Postulate as } \\
\text { other NAEs }\end{array}$ & $\begin{array}{l}\text { Postulate as } \\
\text { other NAEs }\end{array}$ \\
\hline
\end{tabular}


Table 1. Cont.

\begin{tabular}{|c|c|c|c|}
\hline Bioactive Lipids & $\begin{array}{c}\text { Molecular } \\
\text { Targets }\end{array}$ & $\begin{array}{c}\text { Biosynthetic } \\
\text { Enzymes }\end{array}$ & Catabolic Enzymes \\
\hline \multicolumn{4}{|c|}{ Monounsaturated and saturated fatty acids derivatives } \\
\hline PEA & $\begin{array}{c}\text { PPAR } \alpha[42-51] \\
\text { GPR55 [52] } \\
\text { GPR119 [53] }\end{array}$ & $\begin{array}{c}\text { NAT [11] } \\
\text { iNAT [12-14] } \\
\text { NAPE-PLD [15] } \\
\text { Lyso-PLD [16-18] } \\
\text { GDE1[16-18] } \\
\text { PTPN22 [16-18] }\end{array}$ & $\begin{array}{c}\text { FAAH-1 [54] } \\
\text { FAAH-2 [21] } \\
\text { NAAH [55] }\end{array}$ \\
\hline OEA & $\begin{array}{c}\operatorname{PPAR} \alpha[42-51] \\
\text { GPR119 [53] } \\
\text { GPR55[52] }\end{array}$ & $\begin{array}{c}\text { NAT [11] } \\
\text { iNAT [12-14] } \\
\text { NAPE-PLD [15] } \\
\text { ABHD4 [16-18] } \\
\text { Lyso-PLD [16-18] } \\
\text { GDE1[16-18] } \\
\text { PTPN22 [16-18] }\end{array}$ & $\begin{array}{c}\text { FAAH-1 [54] } \\
\text { FAAH-2 [21] } \\
\text { NAAH [55] }\end{array}$ \\
\hline 2-OG & GPR119 [53] & $\begin{array}{c}\text { PLC } \beta[27,28] \\
\text { DAGL } \alpha[29] \\
\text { DAGL } \beta[29]\end{array}$ & $\begin{array}{c}\text { MAGL [30] } \\
\text { FAAH-1 [54] }\end{array}$ \\
\hline
\end{tabular}

Notes: ABHD4, $\alpha / \beta$-hydrolase 4; ABHD6/12, $\alpha / \beta$-hydrolase domain $6 / 12 ; \mathrm{CB}_{1}$, type-1 cannabinoid receptors; $\mathrm{CB}_{2}$, type-2 cannabinoid receptors; COX-2, cyclooxygenase-2; Cyt $\mathrm{P}_{450}$, cytochrome $\mathrm{P}_{450} ; \mathrm{DAGL} \alpha / \beta$, diacylglycerol lipase $\alpha / \beta$; FAAH, fatty acid amide hydrolase; GPR55, orphan G protein-coupled receptor 55 ; LOXs, lipoxygenases; MAGL, monoacylglycerol lipase; NAAA, $N$-acylethanolamine-hydrolyzing acid amidase; NAPE-PLD, $N$-acyl-phosphatidylethanolamines-hydrolyzing phospholipase D; NAT, $N$-acyltransferase; iNAT, $\mathrm{Ca}^{2+}$-independent $N$-acyltransferase; PLC $\beta$, phospholipase C $\beta$; PPAR $\alpha / \gamma$, peroxisome proliferator-activated receptor $\alpha / \gamma$; PTPN22, protein tyrosine phosphatase, non-receptor type 22; TRPV1, transient receptor potential vanilloid type 1 channel.

Additionally, other $\omega-6$ (n-6) fatty acid compounds, including $N$-dihomo- $\gamma$-linolenoylethanolamine, $\mathrm{N}$-arachidonoyldopamine (NADA), 2-arachidonoylglycerylether (noladin ether) and $O$-arachidonoylethanolamine (virodhamine) (Table 1), have also been found to interact with CBRs, though with differing potencies and efficacies as reported in a comprehensive review [1] and summarized in Table 1. Two metabolically important $\omega-3$ (n-3) fatty acid ethanolamines have also been discovered: $N$-eicosapentaenoylethanolamine (EPEA) and $N$-docosahexaenoylethanolamine (DHEA) (Table 1) [56,57]. These n-3 eCBs have been proposed as additional CBRs agonists [58], but their pharmacology and biological relevance remain to be clarified.

The ECS is further complicated by important compounds structurally related to eCBs, and called "eCBs-like" substances. The latter are often found in much higher amounts than AEA, and are devoid of affinity for CBRs; yet, they are metabolized by the same synthesizing and degrading enzymes as authentic eCBs [11]. Among these compounds, the $N$-acyl derivative of palmitic acid and $N$ - and $O$-acyl derivatives of oleic acid (Table 1) are particularly relevant. 
The biological actions of eCBs and congeners are controlled through not yet fully characterized cellular mechanisms, that include key agents responsible for: (i) AEA and 2-AG synthesis, like the $N$-acyl-phosphatidylethanolamines (NAPE)-hydrolyzing phospholipase D (NAPE-PLD) and the $s n$-1-specific diacylglycerol lipase (DAGL), respectively; and (ii) their degradation, like the fatty acid amide hydrolase (FAAH) and the monoacylglycerol lipase (MAGL), respectively. Remarkably, during the last few years multiple pathways have been described for eCBs metabolism (especially for NAEs), and will be described later in this review.

Strong pharmacological and biochemical evidence has demonstrated that eCBs and related molecules are also able to interact with non-CBR targets, increasing the complexity of the ECS and of the molecular pathways trigged thereof. In particular, the best known non-CBR target of eCBs is the transient receptor potential vanilloid type 1 (TRPV1) channel, which is activated by both AEA [8] and 2-AG [26].

Other potential receptors activated by eCBs are peroxisome proliferator-activated receptor (PPAR) $\alpha$ and $\gamma$ [9], and the orphan $G$ protein-coupled receptor GPR55 [10,37,52]. In Table 1 old and new members of the ECS are listed together. The ECS has been shown to regulate different physiological processes in the central nervous system (CNS) and at the periphery [59-63], thereby suggesting that its signaling may foster the development of pathway-selective drugs for therapeutic benefit [39,63-68].

In this review, we present the state of the art on $\mathrm{eCBs}$, related compounds and their metabolic routes with a mention about their potential therapeutic role.

\section{Endocannabinoids System}

Although many GPCRs have endogenous ligands that are hydrophilic cations, CBRs have neutral, highly lipophilic ligands derived from fatty acids. The differences in reciprocal endogenous concentration of eCBs, receptors affinity, and asymmetrical localization (intracellular and tissutal) of their metabolic enzymes support distinct roles for these molecules under various physiological conditions (e.g., in different forms of synaptic plasticity) [2,69-75].

\subsection{Endogenous Ligands of Cannabinoid Receptors}

\subsubsection{Main Endocannabinoids}

The search for endogenous ligands of the THC binding sites has proven difficult at the beginning, because water-soluble substances were searched for by analogy to endorphins. Later on, the lipid nature of THC led to the discovery of two eicosanoids: the $\mathrm{N}$-arachidonoylethanolamine, termed "anandamide" from the Sanskrit word "ananda" for inner bliss [5], and 2-arachidonoylglycerol (Figure 1) [6,7].

Numerous studies have been carried out on AEA since 1992. This eCB was first found in the brain and then in many other organs and fluids [76]. AEA shares many properties with THC, and acts as a partial agonist of $\mathrm{CB}_{1}$ and as a weak partial agonist/antagonist of $\mathrm{CB}_{2}$ [1].

However, it should be pointed out that AEA is present, often in low amounts [72], in areas with high or low density of CBRs, suggesting the possibility that it may activate other receptors [1]. 
The relative low amounts of AEA can be explained by considering the bioavailability of its precursor, and in addition they might suffer from the impossibility to measure accurately their exact local concentration [72].

Instead, the levels of the second eCB, 2-AG, are usually markedly higher than those of AEA in the same tissues [76]. 2-AG acts as a full agonist at CBRs, and has been proposed as the main endogenous agonist for both $\mathrm{CB}_{1}$ and $\mathrm{CB}_{2}$ receptors [1]. The two main eCBs have different affinity for CBRs, in fact 2-AG is engaged in $\mathrm{CB}_{1}$-dependent retrograde signaling, whereas $\mathrm{AEA}$ it is only under some condition, causing the inhibition of presynaptic release of the excitatory neurotransmitter glutamate and/or of the inhibitory neurotransmitter GABA [77-79].

Notably 2-AG, besides acting as an eCB, is also an important intermediate in lipid metabolism and, therefore, its physiological concentrations may not reflect only the amount needed to trigger CBRs [69]. Indeed, 2-AG has long been regarded as a degradation product of inositol phospholipids, and as a possible source of arachidonic acid in stimulated cells. Moreover, when assessing the levels of 2-AG, it is necessary to keep into account that this compound (much alike all 2-acylglycerols) undergoes acyl migration at room temperature in aqueous media, resulting as an equilibrium of predominant 1(3)-AG (90\%) with 2-AG itself (10\%) [80].

Furthermore, although different studies support the hypothesis that the composition of dietary fatty acids can affect the levels of eCBs (and eCBs-like compounds) in a time- and tissue-specific manner [56,81,82], yet no changes in blood eCBs were found with low and high-fat diets in obese and normal-weight subjects but, in the same contest, a modification in the skeletal muscle of $\mathrm{CB}_{1}$ receptors and MAGL was reported [83]. Other studies have shown that a diet low in n-3 polyunsaturated fatty acids in mice induces a deterioration of $\mathrm{CB}_{1}$ receptor functions in the offspring [84]. Notably, the level of eCBs (and eCBs-like compounds) varied depending on the physiological and pathological conditions, and often the content of distinct fatty acid derivatives is regulated independently $[38,85]$ and this different regulation offers the possibility of being able to selectively act on the concentration of the derivative of interest with a potential beneficial effect.

\subsubsection{Additional n-6-Endocannabinoids}

During the past years, different AA derivatives with cannabimimetic properties have been detected, suggesting the existence of new members of the endocannabinoid family. In particular, an ether-type eCB, 2-arachidonoyl-glyceryl ether or noladin ether (Table 1) [84], and an AA and ethanolamine derivative with an ester bond (an "inverted" AEA), called virodhamine (Table 1) [36], have been isolated in the brain. Additionally, $N$-arachidonoyldopamine (NADA), that is primarily a TRPV1 agonist, has some activity at $\mathrm{CB}_{1}$ as well (Table 1) [86]. These compounds have received less attention than the two main eCBs (AEA and 2-AG), maybe due to the difficulty for many researchers to isolate them from biological tissues $[72,87]$.

At any rate, it has been reported that noladin ether binds to $\mathrm{CB}_{1}$ receptors and very weakly to $\mathrm{CB}_{2}$ receptors [35], besides affecting AEA uptake [88]. Moreover, virodhamine has been shown to behave in vitro as a $\mathrm{CB}_{2}$ receptor full agonist, and as a partial agonist of $\mathrm{CB}_{1}$. Instead, in vivo it is an antagonist at $\mathrm{CB}_{1}$, and also a weak inhibitor of AEA uptake [36]. 
Much like AEA, noladin ether and virodhamine interact, although with different affinity, with PPAR $\alpha$ and the orphan GPR55 receptor [9,37,87-91], again suggesting that non-CBRs can be common targets for several fatty acid derivatives.

The last derivative of AA which has been added to the eCBs family has been so far is NADA [86], which shares with AEA, and with its analogue $N$-oleoyldopamine [33], the ability to activate TRPV1. Indeed, NADA has been found in bovine brain areas with elevated density of TRPV1 channels, and is considered a true "endovanilloid" [92]. Furthermore, AEA and NADA seem to share also PPAR $\gamma$ as a target [34]. NADA has been found in brain regions with the highest amounts of dopamine, thus it was suggested to be the product of condensation of this catecholamine with AA [86,93]. Conversely, its inactivation likely goes through a very slow hydrolysis of the amide bond, or through the methylation of the catecholamine moiety by catechol-O-methyl transferase, with the formation of a less potent 3-O-methyl derivative [86].

Besides AEA, other less known $\omega-6$ (n-6) unsaturated NAEs, able to interact with CBRs and endowed with three or four double bonds, are also formed, apparently even in higher amounts than AEA. Among these, the $N$-dihomo- $\gamma$-linolenoylethanolamine has been isolated from different tissues [94,95], as well as from biological fluids [40], where it acts as a weak CBRs agonist, yet with a poorly understood (if any) physiological significance.

\subsection{3. n-3-Endocannabinoids}

Since the 1930s essential roles were assigned to the n-3 polyunsaturated fatty acids (PUFAs), because their lack in the diet gave rise to not yet known forms of deficiency diseases at the time [96]. There is a lot of literature that speaks of the various beneficial effects of PUFAs such as protective effects against cardiovascular disease, inflammation, and cancer [97,98], although there are now several articles that challenge the beneficial effects of these fatty acids [99].

Interestingly, among the molecules capable of activating CBRs metabolites derived from PUFAs were detected. In particular, two derivatives of docosahexaenoic acid (DHA, C22:6) and eicosapentaenoic acid (EPA, C20:5) were found, and were called DHEA and EPEA respectively (Table 1) [39]. Even these n-3 NAEs showed the same promiscuity of the corresponding n-6 analogues, and indeed in addition to bind to CB receptors they are also able to activate PPAR $\gamma$ [41].

Furthermore, n-3 PUFAs and their natural derivatives resolvins can modulate TRPV1 activity [100-102]. In line with this, the bioactive derivative of DHA, resolvin D2, inhibits TRPV1 currents in dorsal root ganglion neurons, although the underlying mechanism does not seem to be direct, but rather mediated by an unknown GPCR [101]. The ability of resolvins to reduce inflammation under physiological conditions [103] makes these molecules very attractive as possible anti-inflammatory/analgesic drugs.

Altogether, endocannabinoid signaling appears rather complex, and seems to be clearly affected by diet (with particular reference to the n-3/n-6 ratio). For instance, DHEA can be found under basal conditions, whereas EPEA is detected in the same cells only when supplied with an appropriate diet [42,57]. These $\mathrm{n}-3$ eCBs have shown anti-inflammatory properties in macrophages [43] and adipocytes [3], and can inhibit cell growth in breast cancer by triggering autophagy via PPAR $\gamma$ [41]. 
Remarkably, oral administration of DHEA has been shown to have beneficial effects in patients who were poor responders to in vitro fertilization treatments [45].

\subsubsection{Endocannabinoid-Like Compounds}

AEA belongs to a class of naturally occurring molecules (NAEs) known for a long time. One of its members, $N$-palmitoylethanolamine (PEA), was first reported almost 50 years ago in humans, yet its physiological relevant remains under debate when the mechanism is other than via CBRs [46].

PEA and other NAEs share with true eCBs many degradative mechanisms, and they potentiate the effect of eCBs at their receptor targets by competitively inhibiting their hydrolysis, or by allosterically modulating their receptor binding: the so-called "entourage effect" [47,48]. On this basis, these substances are also known as "eCBs-like" compounds (Table 1).

Among the most studied eCBs-like compounds, the anti-inflammatory agent PEA and the appetite-suppressor $N$-oleoylethanolamine (OEA) can be listed (Table 1) [46]. Their biological activity often engages PPAR $\alpha$ and TRPV1 activation [47-51], although some of their actions are prevented by $\mathrm{CB}_{1}$ antagonists [104,105]. Among the eCBs-like compounds OEA shows the highest affinity for PPAR $\alpha$ [106], and consistently some of its biological effects are absent in PPAR $\alpha$ deficient mice [107]. Yet, the antinociceptive properties of OEA are exercised also through a PPAR $\alpha$-independent mechanism [108].

OEA, as well as PEA and 2-oleoylglycerol (2-OG) (Table 1), can also activate GPR119, a GPCR expressed predominantly in human and rat pancreas [53], suggesting that the effects of OEA on food intake may be mediated, at least in part, via GPR119 [53,109,110]. Conversely, Lan and coworkers reported that the hypophagic effect of OEA was preserved in Gpr119(-/-) mice [111]. Not surprisingly, there is also evidence that OEA (as well as PEA) can engage, even though at high concentrations, additional receptors like GPR55 [52].

Another saturated NAE, $N$-stearoylethanolamine (SEA), was reported to act as a cell growth controller and anti-inflammatory/immunomodulatory agent, through yet unknown targets $[46,112,113]$. SEA also shows anorexic effects that are PPAR-independent [114] and, together with PEA, plays an antinociceptive role in humans [114].

As reported above, also the endogenous levels of these eCBs-like compounds (PEA, OEA and SEA) are affected by different dietary regimens, with different hits in the brain compared to peripheral tissues [56,82].

Recent advancement of analytical techniques has allowed to detect a large variety of compounds containing fatty acid chains conjugated with different polar heads [87,115,116]. Within these novel lipids, $N$-arachidonoylglycine (NArGly) and $N$-arachidonoylserine (NArS) (Figure 2) as arachidonoyl-amino acids can be listed [53,109-120].

NAGly, that differs from AEA only for the oxidation of the $\beta$ carbon, acts as a high affinity ligand for GPR18 [121-123], and as a partial agonist of Gq/11-coupled GPR92 receptors [124]. NAGly was first showed to be a potent in vitro FAAH inhibitor [125], and later on it was shown to occur naturally in vivo, to mimic the pharmacological profile of abnormal cannabidiol [119], and to exert an indirect neuroprotective effect through $\mathrm{CB}_{2}$ and TRPV1, but not $\mathrm{CB}_{1}$ or GPR55, receptors [126]. 
Figure 2. Chemical structures of some endocannabinoid-like molecules.

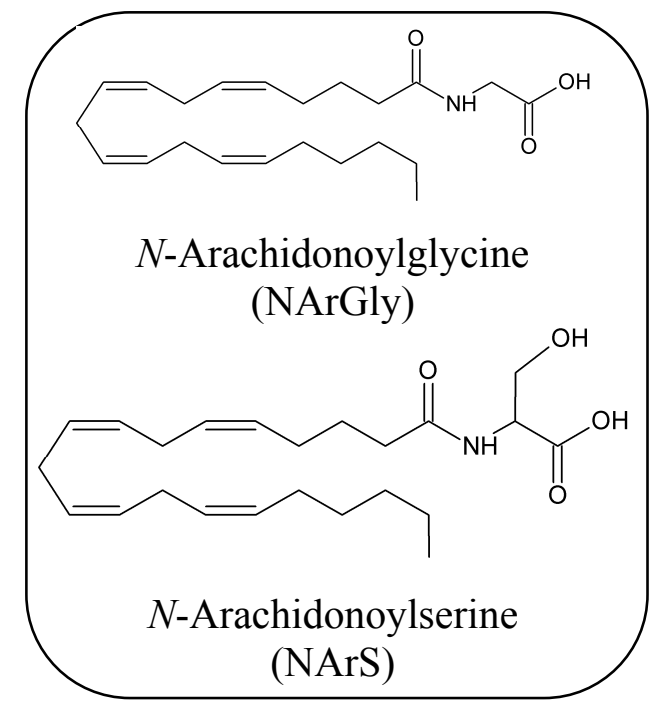

Although further investigations are necessary to elucidate the actual physiological relevance of eCBs-like compounds and arachidonoyl-amino acids, it is important to point out that PEA, due to the lack of adverse side-effects at central $\mathrm{CB}_{1}$ receptors holds potential for the development of innovative medicine, and it is currently marketed to cure neuropathic and pelvic pain [127].

\subsection{Metabolism of Endocannabinoids and Related Compounds}

Much like many other bioactive molecules, the activity of eCBs is controlled by their endogenous levels, and therefore by a balance between biosynthetic and degradative mechanisms. Based on original observations carried out on AEA [128], it was postulated that eCBs are not stored in pre-formed vesicles, yet they are rather synthesized and released "on demand", i.e., when and where needed. However, more recent views have imposed a reconsideration of this "dogma", because AEA can be stored in lipid droplets (adiposomes) and is bound to intracellular transporters [2,129]. A modern view of the metabolic pathways of AEA and 2-AG (and related substances) is presented in the next sections.

\subsubsection{Biosynthesis of AEA and Congeners}

The ever-growing number of enzymes involved in the biosynthesis of AEA (and related NAEs) suggests that the endogenous tone of this $\mathrm{eCB}$ is subjected to a highly complex and highly regulated network of reactions (Scheme 1).

The main route for NAEs biosynthesis consists of two enzymatic reactions. The first is a fatty acyl chain transfer from membrane phospholipids to a phosphatidylethanolamine, resulting in the formation of $N$-acylphosphatidylethanolamine (NAPE), by a yet-unidentified $\mathrm{Ca}^{2+}$-dependent $N$-acyltransferase (NAT) [11] or a $\mathrm{Ca}^{2+}$-independent counterpart (iNAT) [12-14]. Being the palmitoyl and oleoyl acids preferentially incorporated in $s n-1$ position, NAT preferably produces PEA and OEA rather than AEA [11]. Instead, iNAT removes a fatty acyl group from both the $s n-1$ position and the $s n-2$ position (where AA is most abundant) of phosphatidylcholine (PC), that is the acyl donor $[13,14]$. 
Scheme 1. The alternative biosynthetic and degradative pathways of AEA and congeners.

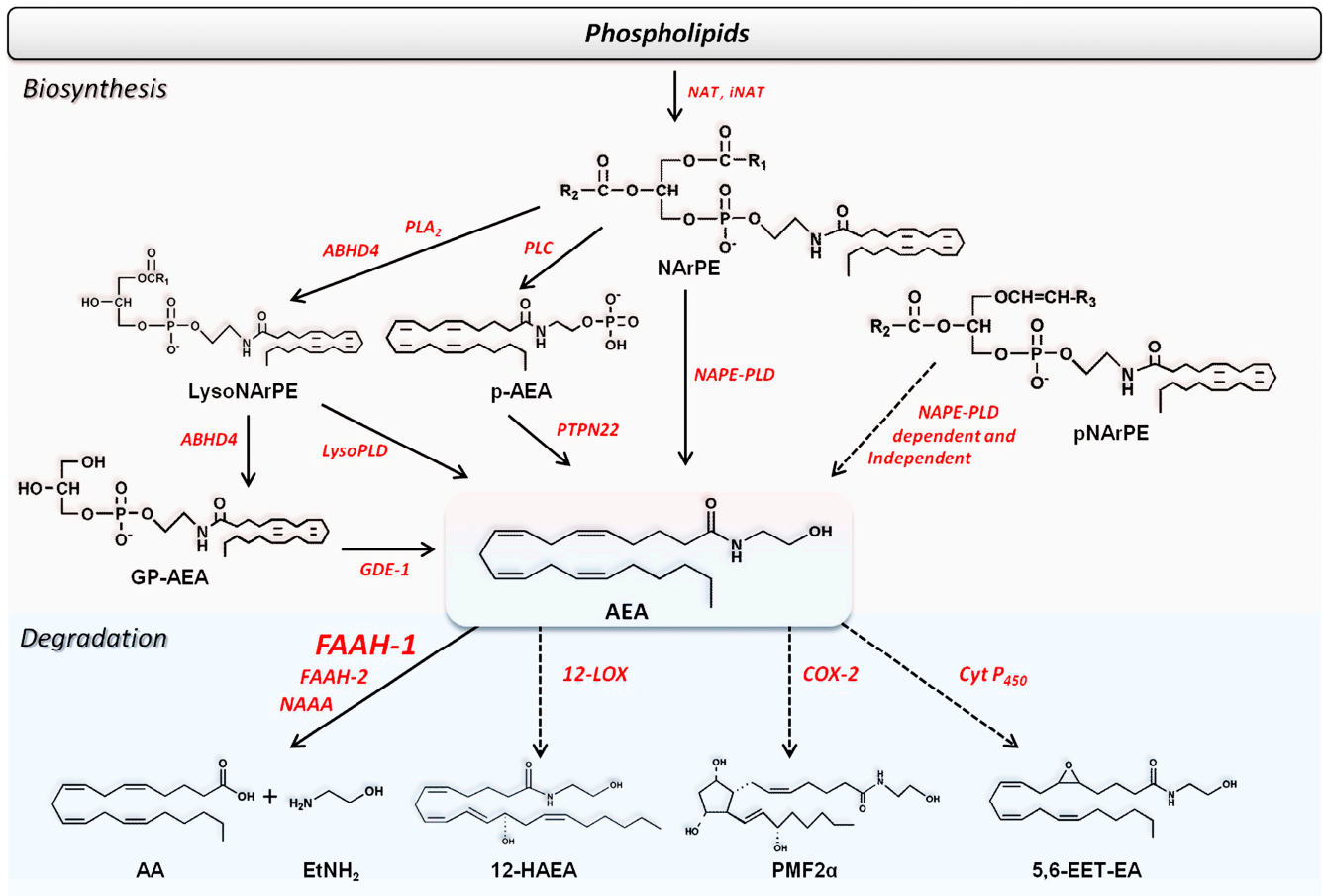

Notes: NAAA, N-acylethanolamine-hydrolyzing acid amidase; NArPE, $N$-arachidonoylphosphatidylethanolamine; pNArPE, $N$-arachidonoylethanolamine plasmalogen; ABHD4, $\alpha / \beta$-hydrolase 4; NAPE-PLD, $N$-acyl-phosphatidylethanolamines-hydrolyzing phospholipase D; AA, arachidonic acid; COX-2, cyclooxygenase-2; Cyt $\mathrm{P}_{450}$, cytochrome $\mathrm{P}_{450}$; EET-EA, epoxyeicosatrienoyl ethanolamides; $\mathrm{EtNH}_{2}$, ethanolamine; FAAH, fatty acid amide hydrolase; GP-AEA, glycerophospho-AEA; GDE1, glycerophosphodiester phosphodiesterase 1; 12-HAEA, 12-hydroxyanandamide; lyso-NArPE, lyso- $N$-arachidonoylphosphatidylethanolamine; 12-LOX, 12-lipoxygenase; pAEA, phospho-AEA ; NAT, $N$-acyl-transferase; iNAT, $\mathrm{Ca}^{2+}$-independent $N$-acyltransferase; PMF2 $\alpha$, prostamides F2 $\alpha$; PLA phospholipase $\mathrm{A}_{2}$; PLC, phospholipase $\mathrm{C}$; lyso-PLD, lyso-phospholipase D; PTPN22, protein tyrosine phosphatase, non-receptor type 22 .

Furthermore, NAT and iNAT have different cellular and tissue localizations, for example the latter is poorly expressed in the brain [11] suggesting a distinct role in the control of NAEs levels.

The second step is catalyzed by a type D phospholipase (NAPE-PLD) (Scheme 1), that is distinct from the classical PLDs. Indeed NAPE-PLD, that is highly conserved from rodents to human belongs to the metallo-lactamase family of enzymes, and in vitro it catalyzes the formation of AEA from its C20:4-NAPE precursor, as well as by other NAPEs [15].

Accumulated evidence indicates, however, the existence of additional pathways for AEA formation from NArPE $[11,130]$. Indeed, through the use of knock-out mice several enzymes and metabolites involved in the NAPE-PLD-independent biosynthesis of AEA have been identified and characterized [16-18]. These alternative pathways of AEA are shown in Scheme 1. More recently, an interesting paper reported a novel route for NAEs formation from $N$-acylethanolamine plasmalogen (1-alkenyl-2-acyl-glycero-3-phospho( $N$-acyl)ethanolamine, pNAPE), one of the major classes of glycerophospholipids in mouse brain [131]. Also this route is depicted in Scheme 1. 


\subsubsection{Biosynthesis of $2-\mathrm{AG}$ and Congeners}

The best known biosynthetic pathway for 2-AG requires the combined action of two membrane enzymes: phospholipase C (PLC) and diacylglycerol lipase (DAGL), as shown in Scheme 2. In particular, between various PLC isoforms [132], $\beta 1$ and $\beta 4$ have been linked to 2-AG formation triggered by GPCRs in hippocampal neurons and cerebellar Purkinje cells, respectively [27,28]. Moreover, since PLC recognizes different phospholipids, the distribution of which varies among tissues, formation of DAG, and then of 2-AG, by such a lipase is tissue-specific [133,134]. Alternative pathways of 2-AG biosynthesis are shown in Scheme 2.

Scheme 2. The alternative biosynthetic and degradative pathways of 2-AG and congeners.

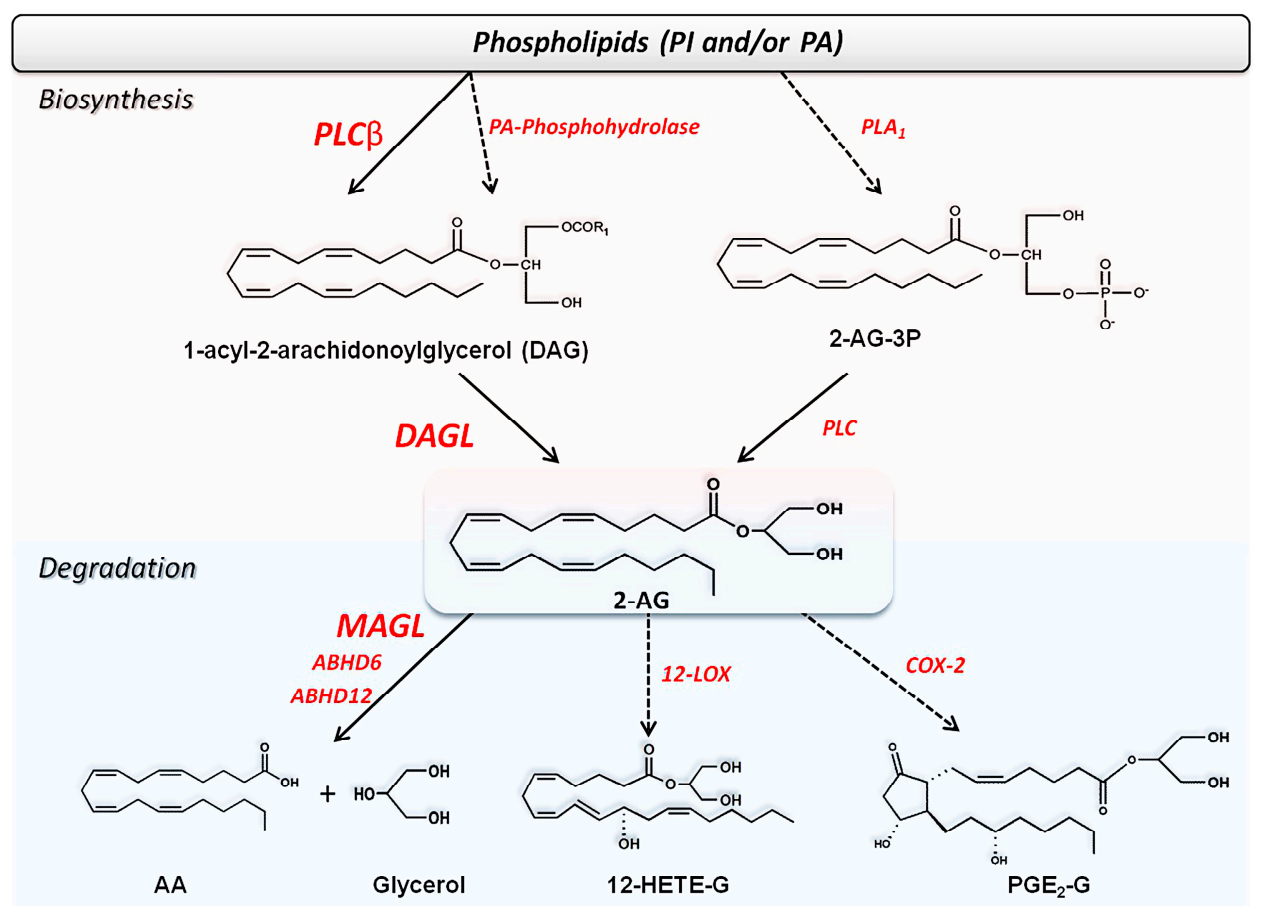

Notes: AA, arachidonic acid; 2-AG-3P, 2-arachidonoylglycerol-3-phosphate; COX-2, cyclooxygenase-2; DAG, diacylglycerol; DAGL, diacylglycerol lipase; 12-HETE-G, 12-hydroxyarachidonoyl-glycerol; ABHD6/12, $\alpha / \beta$-hydrolase domain 6/12; 12-LOX, 12-lipoxygenase; MAGL, monoacylglycerol lipase; PLC, phospholipase C; PLC $\beta$, phospholipase $\mathrm{C} \beta ; \mathrm{PGE}_{2}-\mathrm{G}$, prostaglandinglycerol $\mathrm{E}_{2}-\mathrm{G}$.

DAGL, the second enzyme involved in 2-AG formation, is present in two forms, $\alpha$ and $\beta$ [29]. Thus, the high content of AA at the latter position can explain the predominant production of 2-AG over other MAGs [29]. Remarkably, two independent studies have suggested that only 2-AG generated by DAGL $\alpha$ is responsible for retrograde suppression through $\mathrm{CB}_{1}$ at central synapses in the brain $[135,136]$. Furthermore, decreased AEA levels in the cerebellum and hippocampus of dagla-/mice have been reported [136], supporting a mutual interaction between AEA and 2-AG, possibly engaging also TRPV1 channels as documented in the striatum [137]. Additionally, a regulation of DAGL $\alpha$ by calcium/calmodulin-dependent protein kinase II was reported [138], and such a protein kinase had been previously shown to regulate also TRPV1 receptor [139]. The alternative pathways of 2-AG biosynthesis are shown in Scheme 2. 


\subsubsection{Degradation of Endocannabinoids and Congeners}

Uptake of Endocannabinoids and Congeners

At the beginning the mechanism involved in eCBs transmembrane transport that received most attention was facilitated transport [140-142], yet no transporter protein has been yet cloned. Then, additional mechanisms have been proposed, that have been recently reviewed [143]: (i) passive diffusion gated by FAAH [144,145], by intracellular sequestration [146], or by the formation of AEA-cholesterol complexes [147]; (ii) caveolae-dependent endocytosis [143].

Another hot topic is the understanding of how eCBs can reach their distinct sites of action within the cell (e.g., membrane or nuclear receptors, or metabolic enzymes) at the right time, in order to trigger the appropriate response to a stimulus. In this context, the existence of intracellular storage organelles (lipid droplets or adiposomes) [146], and of constitutive intracellular transporters (AEA intracellular transporters, AITs) have been reported for AEA. Among constitutive AITs are heat shock protein 70 (Hsp70) and albumin [148], to which fatty acid binding proteins 5 and 7 (FABP5 and FABP7) have been added as exogenous entities [149]. Interestingly, a functional role for FABPs in endocannabinoid signaling has been recently documented [150], providing a proof of concept that indeed AITs can drive endocannabinoid signaling through a distinct pathway (e.g., the one triggered via PPAR $\alpha$ by OEA [150].

Moreover, it has been suggested that some NAEs are accumulated in cells via a general mechanism shared with AEA [151], which can operate in a bi-directional mode [141,151,152]. Interestingly, PEA has been shown to interfere with AEA transmembrane transport in a cell type-dependent manner [153], and several analogs of OEA were shown to be more powerful than NAEs containing AA in blocking AEA uptake [128]. Less information is available on the cellular accumulation of other eCBs analogues, yet at least one double bond in the acyl chain seems necessary for the transmembrane transport to take place $[143,154]$.

As yet, only a few studies have addressed the transport of 2-AG, but apparently this eCB uses the same mechanism used by AEA $[151,155,156]$. In addition, 2-AG can be directly esterified into (phospho)glycerides, via phosphorylation and/or acylation of its free hydroxyl groups [156].

In conclusion, the following citation appears quite instructive: "Translocation across the plasma membrane is achieved by a concert of co-existing mechanisms. These lipids can passively diffuse, but transport can also be accelerated by certain membrane proteins as well as lipid rafts" [157].

\section{Hydrolysis of AEA and Congeners}

Probably the main catabolic enzyme responsible for signal termination of AEA is fatty acid amide hydrolase (FAAH) [19]. This enzyme has been cloned by Cravatt and coworkers in 1996 [35,54], and shown to break down AEA, as well as other NAEs and also 2-AG (Table 1 and Scheme 1).

FAAH is an intracellular membrane-bound serine hydrolase with S241-S217-K142 as catalytic triad $[158,159]$. This hydrolase is widely present in the brain, where it shows a subcellular distribution that overlaps on that of $\mathrm{CB}_{1}$ receptors, and in virtually all peripheral organs, yet with a different distribution between rodents and humans [158]. 
A few years after the characterization of FAAH (now called FAAH-1), two other hydrolases able to hydrolyze AEA, were reported and recently revisited [55]: an isoform of FAAH that is known as FAAH-2 [20], and a lysosomal cysteine hydrolase termed $N$-acylethanolamine-hydrolyzing acid amidase (NAAA) (Scheme 1) [21]. In particular, FAAH-2 has a limited species distribution in mammals, and appears to be permanently-associated with adiposomes [160], where AEA can be stored, and was localized also on lipid droplets [146]. FAAH-1 and FAAH-2 share limited sequence identity $(\sim 20 \%)$, while no homology exists between them and NAAA [21], an enzyme that shows a substrate preference toward other saturated or monounsaturated NAEs [55]. Interestingly, several potent NAAA inhibitors have been shown to potentiate the effect of PEA at PPAR $\alpha[161,162]$. Instead, the primary role of FAAH-1 appears to control the in vivo levels of AEA and other polyunsaturated NAEs, as confirmed by FAAH1-/- mice [163].

Hydrolysis of 2-AG and Congeners

Solid evidence demonstrates that monoacylglycerol lipase (MAGL) is the main responsible for 2-AG degradation in vivo (Table 1 and Scheme 2). Indeed, hydrolysis and content of 2-AG remain unchanged in FAAH1-/- mice, while they markedly increased in MAGL-/- mice [30], and were associated with profound changes in 2-AG signaling [164]. Furthermore, the different localization of MAGL and FAAH-1 in the brain [30,70] supports the hypothesis of distinct roles for these two eCBs [165].

Interestingly, MAGL exhibits higher specificity than FAAH-1, because treatment with its potent and selective inhibitor JZL-184 rises only the levels of 2-AG, without affecting those of any other MAG (e.g., monopalmitoylglycerol and monooleoylglycerol) [166]. MAGL is a serine hydrolase with a catalytic triad (S122-D239-H269) that is highly conserved among different species [166-170]. Interestingly, different observations support a role for MAGL as a provider of free fatty acids, that sustains cancer [171-173].

Two additional serine hydrolases, $\alpha / \beta$-hydrolase domain 6 (ABHD6, with a postulated catalytic triad S148-D278-H306) and 12 (ABHD12, with a postulated catalytic triad S246-D333-H372), are involved in 2-AG hydrolysis (Table 1 and Scheme 2) [31,32]. Of note, MAGL, ABHD6 and ABHD12 show a distinct distribution within the CNS [32,174], that is suggestive of a different physiological function of these three enzymes in regulating 2-AG signaling [32,175]. In support of this view, anti-inflammatory effects of ABHD6 inhibition without the side effects typically associated with MAGL inhibition have been recently reported [176].

Furthermore, mutations in abhd12 gene are associated with the neurodegenerative disease called PHARC (polyneuropathy, hearing loss, ataxia, retinitis pigmentosa, and cataract) [177]. It could speculate that this inherited disease can be linked to a dysfunction of the 2-AG metabolism, although a recent study on ABHD12 $2^{-/}$mice would seem to involve the ECS in this disease [178].

Oxidative Metabolism of eCBs and eCBs-Like Compounds

Alternatively to hydrolytic routes, eCBs are also substrates of the enzymes that oxygenate AA. These catabolic pathways represent an interesting point of intersection between endocannabinoid and classical eicosanoid systems, leading to the production of new biologically active metabolites [23]. 
In particular, AEA and 2-AG are metabolized by lipoxygenases (LOXs) [22] and by cyclooxygenase-2 (COX-2) [23,24], and additionally AEA can be oxygenated also by cytochrome $\mathrm{P}_{450}$ (Table 1). [25]. The main products of the oxidative metabolism of AEA and 2-AG are reported in Schemes 1, 2 and Figure 3.

Several pharmacological data point to LOX-derivatives of AEA (hydroxyanandamides, HAEAs) as ligands for $\mathrm{CB}_{1}, \mathrm{CB}_{2}$, PPARs, and TRPV1 receptors [179-181], and they can also interact with some enzymes of the ECB system [22,182], as well as with cell membranes properties [183,184].

In addition to AEA, other fatty acid derivatives like DHEA, NArGly and $N$-arachidonoyltaurine undergo LOX-catalyzed oxygenation [185-187]. In particular, 17-hydroxy-DHEA (Figure 3) occurs naturally in mouse brain, where it appears to exert a protective function [185].

Figure 3. Chemical structures of the main products of oxidative metabolism of AEA and 2-AG.

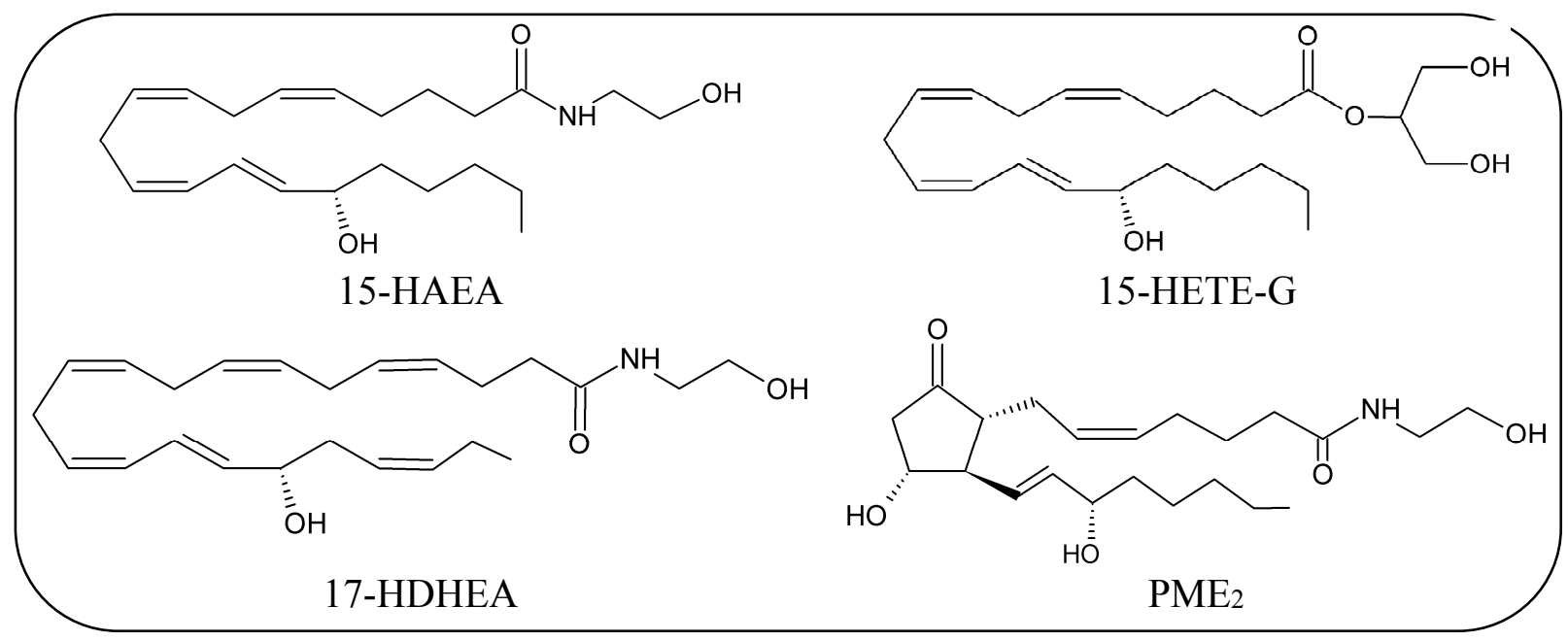

COX-2, but not COX-1, can oxygenate the main eCBs generating a number of oxygenated molecules [23]. By analogy with prostanoids, the products of AA oxygenation by COX-2, AEA and 2-AG can be oxygenated to leads to prostaglandin ethanolamides (prostamides, PMs) and prostaglandin glycerol esters (PGs-G), respectively (Schemes 1, 2 and Figure 3) [188]. Unlike LOX-generated derivatives of eCBs, the biological activities of COX-2-derived metabolites are probably mediated by distinct receptors compared to those that bind eCBs $[23,183,189]$. Interestingly, a number of weak inhibitors of AA oxygenation by COX-2, like nonsteroidal anti-inflammatory drugs (NSAIDs), are potent inhibitors of endocannabinoid oxygenation by the same enzyme [190,191], suggesting that NSAIDs may be useful to better understand the pharmacological properties of PMs in vivo. Interestingly, an increase of prostamide $\mathrm{F}_{2 \alpha}\left(\mathrm{PMF}_{2 \alpha}\right)$ was found in the spinal cord in mice, after induction of inflammation, and was found to exert a proalgesic effect, supporting the relevance of endocannabinoid oxidation in vivo [192]. Furthermore, the $\mathrm{PMF}_{2 \alpha}$ analogue bimatoprost is currently used for the treatment of glaucoma [193]. More recently, prostaglandin $\mathrm{D}_{2}$-glycerol ester was found to decrease macrophage activation, and this effect was dependent on ABDH6 activity [176].

Finally, AEA can be metabolized by several different human cytochromes $\mathrm{P}_{450}$, to form a number of structurally related epoxyeicosatrienoic ethanolamides (EETs-EA) [185]. In particular, AEA epoxide at positions C5-C6 (5,6-EET-EA) (Scheme 1) is generated by human CYP3A4, an isoform of cytochrome $\mathrm{P}_{450}$, and acts as a potent and selective agonist of $\mathrm{CB}_{2}$ receptors [194]. Instead, the orphan 
cytochrome $\mathrm{P}_{450} 4 \mathrm{X} 1$ was found to produce 14,15-EET-EA, whose (patho)physiological relevance remains to be clarified [195].

\section{Conclusions}

The ubiquity of eCBs and their multiple (patho)physiological implications has allowed to identify novel targets for next generation therapeutics; yet, the numerous side effects at the central and peripheral levels may dampen enthusiasm towards these new targets. Indeed, recently they led to the withdrawal of Acomplia ${ }^{\circledR}$ (rimonabant), a $\mathrm{CB}_{1}$ receptor antagonist/inverse agonist that was licensed and marketed as an anti-obesity agent [67].

However, over the last 20 years eCBs-related drugs have indeed been commercially available, such as Cesamet ${ }^{\circledR}$ (nabilone, a synthetic cannabinoid) and Marinol ${ }^{\circledR}$ (dronabinol, a synthetic THC), that are preparations used to treat nausea and vomiting associated to cancer chemotherapy. The latter drug is also prescribed to manage the loss of appetite in people with acquired immunodeficiency syndrome (AIDS). In addition Sativex ${ }^{\circledR}$, a medicine that contains THC and cannabidiol at a 1:1 ratio, has been licensed for the symptomatic treatment (pain, spasticity and incontinence) of multiple sclerosis patients in a (ever-growing) number of countries (e.g., United Kingdom, Canada, New Zealand and United States of America). Furthermore, PEA is currently marketed to cure neuropathic $\left(\right.$ Normast $^{\circledR}$ ) and pelvic $\left(\right.$ Pelvilen ${ }^{\circledR}$ ) pain, and is one of the main components of a cream (Physiogel ${ }^{\circledR}$ ) used for inflamed or irritated skin of subjects with atopic dermatitis.

To this aim, modulators of endocannabinoid metabolic routes have been tested, with a promise to be free of unwanted side effects typical of compounds that activate eCBs-binding receptors. These studies have led to opposite results, the FAAH blockade did not lead to desensitization of CB1 receptors [196], while the chronic pharmacological inactivation of MAGL causes alterations in $\mathrm{CB}_{1}$ receptor function [197]. In conclusion, the development of eCBs-based drugs with a restricted target area appears very promising to cure or slow down different human pathologies.

\section{Acknowlwdgments}

The authors wish to thank all colleagues at Tor Vergata University of Rome, IRCCS Santa Lucia Foundation of Rome and Campus Bio-Medico University of Rome. This investigation was supported by funding from the Italian Ministero dell'Istruzione, dell'Università e della Ricerca to MM (grant PRIN 2010-2011) and to FF (grant PRIN 2012).

\section{Author Contributions}

FF and MB wrote the manuscript; RF, ET, and MF collected data from the literature and prepared table, figures and schemes; MM designed and revised the manuscript. All authors have read and approved the manuscript.

\section{Conflicts of Interest}

The authors declare no conflict of interest. 


\section{References}

1. Pertwee, R.G.; Howlett, A.C.; Abood, M.E.; Alexander, S.P.; Di Marzo, V.; Elphick, M.R.; Greasley, P.J.; Hansen, H.S.; Kunos, G.; Mackie, K.; et al. International Union of Basic and Clinical Pharmacology. LXXIX. Cannabinoid receptors and their ligands: beyond $\mathrm{CB}_{1}$ and $\mathrm{CB}_{2}$. Pharmacol. Rev. 2010, 62, 588-631.

2. Maccarrone, M.; Dainese, E.; Oddi, S. Intracellular trafficking of anandamide: new concepts for signaling. Trends Biochem. Sci. 2010, 35, 601-608.

3. Piomelli, D. More surprises lying ahead. The endocannabinoids keep us guessing. Neuropharmacology 2014, 76, 228-234.

4. Di Marzo, V.; Fontana, A. Anandamide, an endogenous cannabinomimetic eicosanoid: 'Killing two birds with one stone'. Prostaglandins Leukot. Essent. Fat. Acids 1995, 53, 1-11.

5. Devane, W. A.; Hannus, L.; Breuer, A.; Pertwee, R.G.; Stevenson, L.A.; Griffin, G.; Gibson, D.; Mandelbaum, A.; Etinger, A.; Mechoulam, R. Isolation and structure of a brain constituent that binds to the cannabinoid receptor. Science 1992, 258, 1946-1949.

6. Mechoulam, R.; Ben-Shabat, S.; Hanus, L.; Ligumsky, M.; Kaminski, N.E.; Schatz, A.R.; Gopher, A.; Almog, S.; Martin, B.R.; Compton, D.R.; et al. Identification of an endogenous 2-monoglyceride, present in canine gut, that binds to cannabinoid receptors. Biochem. Pharmacol. 1995, 50, 83-90.

7. Sugiura, T.; Kondo, S.; Sukagawa, A.; Nakane, S.; Shinoda, A.; Itoh, K.; Yamashita, A.; Waku, K. Arachidonoylglycerol: A possible endogenous cannabinoid receptor ligand in brain. Biochem. Biophys. Res. Commun. 1995, 215, 89-95.

8. Di Marzo, V.; de petrocellis, 1. Endocannabinoids as regulators of transient receptor potential (TRP) channels: A further opportunity to develop new endocannabinoid-based therapeutic drugs. Curr. Med. Chem. 2010, 17, 1430-1449.

9. Pistis, M.; Melis, M. From surface to nuclear receptors: The endocannabinoid family extends its assets. Curr. Med. Chem. 2010, 17, 1450-1467.

10. Gasperi, V.; Dainese, E.; Oddi, S.; Sabatucci, A.; Maccarrone, M. GPR55 and its interaction with membrane lipids: Comparison with other endocannabinoid-binding receptors. Curr. Med. Chem. 2013, 20, 64-78.

11. Ueda, N.; Tsuboi, K.; Uyama, T. Metabolism of endocannabinoids and related $N$-acylethanolamines: Canonical and alternative pathways. FEBS J. 2013, 280, 1874-1894.

12. Golczak, M.; Kiser, P.D.; Sears, A.E.; Lodowski, D.T.; Blaner, W.S.; Palczewski, K. Structural basis for the acyltransferase activity of lecithin:retinol acyltransferase-like proteins. Biol. Chem. 2012, 287, 23790-23807.

13. Jin, X.H.; Okamoto, Y.; Morishita, J.; Tsuboi, K.; Tonai, T.; Ueda, N. Discovery and characterization of a $\mathrm{Ca} 2+-$ independent phosphatidylethanolamine $\mathrm{N}$-acyltransferase generating the anandamide precursor and its congeners. J. Biol. Chem. 2007, 282, 3614-3623.

14. Jin, X.H.; Uyama, T.; Wang, J.; Okamoto, Y.; Tonai, T.; Ueda, N. cDNA cloning and characterization of human and mouse $\mathrm{Ca}(2+)$-independent phosphatidylethanolamine $N$-acyltransferases. Biochim. Biophys. Acta 2009, 1791, 32-38. 
15. Okamoto, Y.; Morishita, J.; Tsuboi, K.; Tonai, T.; Ueda, N. Molecular characterization of a phospholipase D generating anandamide and its congeners. J. Biol. Chem. 2004, 279, 52985305.

16. Simon, G.M.; Cravatt, B.F. Characterization of mice lacking candidate N-acyl ethanolamine biosynthetic enzymes provides evidence for multiple pathways that contribute to endocannabinoid production in vivo. Mol. Biosyst. 2010, 6, 1411-1418.

17. Liu, J.; Wang, L.; Harvey-White, J.; Osei-Hyiaman, D.; Razdan, R.; Gong, Q.; Chan, A.C.; Zhou, Z.; Huang, B.X.; Kim, H.Y.; et al. A biosynthetic pathway for anandamide. Proc. Natl. Acad. Sci. USA 2006, 103, 13345-13350.

18. Sun, Y.X.; Tsuboi, K.; Okamoto, Y.; Tonai, T.; Murakami, M.; Kudo, I.; Ueda, N. Biosynthesis of anandamide and N-palmitoylethanolamine by sequential actions of phospholipase A2 and lysophospholipase D. Biochem. J. 2004, 380, 749-756.

19. McKinney, M.K.; Cravatt, B.F. Structure and function of fatty acid amide hydrolase. Annu. Rev. Biochem. 2005, 74, 411-432.

20. Wei, B.Q.; Mikkelsen, T. S.; McKinney, M.K.; Lander, E.S.; Cravatt, B.F. A second fatty acid amide hydrolase with variable distribution among placental mammals. J. Biol. Chem. 2006, 281, 36569-36578.

21. Tsuboi, K.; Takezaki, N.; Ueda, N. The N-acylethanolamine-hydrolyzing acid amidase (NAAA). Chem. Biodivers. 2007, 4, 1914-1925.

22. Van der Stelt, M.; van Kuik, J.A.; Bari, M.; van Zadelhoff, G.; Leeflang, B.R.; Veldink, G.A.; Finazzi-Agrò, A.; Vliegenthart, J.F.; Maccarrone, M. Oxygenated metabolites of anandamide and 2-arachidonoylglycerol: Conformational analysis and interaction with cannabinoid receptors, membrane transporter, and fatty acid amide hydrolase. J. Med. Chem. 2002, 45, 3709-3720.

23. Rouzer, C.A.; Marnett, L.J. Endocannabinoid oxygenation by cyclooxygenases, lipoxygenases, and cytochromes P450: Cross-talk between the eicosanoid and endocannabinoid signaling pathways. Chem. Rev. 2011, 111, 5899-5921.

24. Funk, C.D. Prostaglandins and leukotrienes: Advances in eicosanoid biology. Science 2001, 294, 1871-1875.

25. Snider, N.T.; Walker, V.J.; Hollenberg, P.F. Oxidation of the endogenous cannabinoid arachidonoyl ethanolamide by the cytochrome $\mathrm{P}_{450}$ monooxygenases: Physiological and pharmacological implications. Pharmacol. Rev. 2010, 62, 136-154.

26. Zygmunt, P.M.; Ermund, A.; Movahed, P.; Andersson, D.A.; Simonsen, C.; Jönsson, B.A.; Blomgren, A.; Birnir, B.; Bevan, S.; Eschalier, A.; et al. Monoacylglycerols activate TRPV1-a link between phospholipase C and TRPV1. PLoS One 2013, 8, e81618.

27. Hashimotodani, Y.; Ohno-Shosaku, T.; Tsubokawa, H.; Ogata, H.; Emoto, K.; Maejima, T.; Araishi, K.; Shin, H.S.; Kano, M. Phospholipase Cbeta serves as a coincidence detector through its $\mathrm{Ca}^{2+}$ dependency for triggering retrograde endocannabinoid signal. Neuron 2005, 45, 257-268.

28. Maejima, T.; Oka, S.; Hashimotodani, Y.; Ohno-Shosaku, T.; Aiba, A.; Wu, D.; Waku, K.; Sugiura, T.; Kano, M. Synaptically driven endocannabinoid release requires $\mathrm{Ca}^{2+}$-assisted metabotropic glutamate receptor subtype 1 to phospholipase Cbeta4 signaling cascade in the cerebellum. J. Neurosci. 2005, 25, 6826-6835. 
29. Bisogno, T.; Howell, F.; Williams, G.; Minassi, A.; Cascio, M.G.; Ligresti, A.; Matias, I.; Schiano-Moriello, A.; Paul, P.; Williams, E.J.; et al. Cloning of the first sn1-DAG lipases points to the spatial and temporal regulation of endocannabinoid signaling in the brain. J. Cell Biol. 2003, 163, 463-468.

30. Chanda, P.K.; Gao, Y.; Mark, L.; Btesh, J.; Strassle, B.W.; Lu, P.; Piesla, M.J.; Zhang, M.Y.; Bingham, B.; Uveges, A.; et al. Monoacylglycerol lipase activity is a critical modulator of the tone and integrity of the endocannabinoid system. Mol. Pharmacol. 2010, 78, 996-1003.

31. Blankman, J.L.; Simon, G.M.; Cravatt, B.F. A comprehensive profile of brain enzymes that hydrolyze the endocannabinoid 2-arachidonoylglycerol. Chem. Biol. 2007, 14, 1347-1356.

32. Marrs, W.R.; Blankman, J.L.; Horne, E.A.; Thomazeau, A.; Lin, Y.H.; Coy, J.; Bodor, A.L.; Muccioli, G.G.; Hu, S.S.; Woodruff, G.; et al. The serine hydrolase ABHD6 controls the accumulation and efficacy of 2-AG at cannabinoid receptors. Nat. Neurosci. 2010, 13, 951-957.

33. Chu, C.J.; Huang, S.M.; de Petrocellis, L.; Bisogno, T.; Ewing, S.A.; Miller, J.D.; Zipkin, R.E.; Daddario, N.; Appendino, G.; Di Marzo, V.; et al. Noleoyldopamine, a novel endogenous capsaicin-like lipid that produces hyperalgesia. J. Biol. Chem. 2003, 278, 13633-13639.

34. O'Sullivan, S.E. Cannabinoids go nuclear: Evidence for activation of peroxisome proliferator-activated receptors. Br. J. Pharmacol. 2007, 152, 576-582.

35. Hanus, L.; Abu-Lafi, S.; Fride, E.; Breuer, A.; Vogel, Z.; Shalev, D.E.; Kustanovich, I.; Mechoulam, R. 2-Arachidonyl glyceryl ether, an endogenous agonist of the cannabinoid $\mathrm{CB}_{1}$ receptor. Proc. Natl. Acad. Sci. USA 2001, 98, 3662-3665.

36. Porter, A.C.; Sauer, J.M.; Knierman, M.D.; Becker, G.W.; Berna, M.J.; Bao, J.; Nomikos, G.G.; Carter, P.; Bymaster, F.P.; Leese, A.B.; et al. Characterization of a novel endocannabinoid, virodhamine, with antagonist activity at the $\mathrm{CB}_{1}$ receptor. J. Pharmacol. Exp. Ther. 2002, 301, 1020-1024.

37. Ross, R.A. The enigmatic pharmacology of GPR55. Trends Pharmacol. Sci. 2009, 30, 156-163.

38. Ligresti, A.; Petrosino, S.; Di Marzo, V. From endocannabinoid profiling to "endocannabinoid therapeutics". Curr. Opin. Chem. Biol. 2009, 13, 321-331.

39. Brown, I.; Cascio, M.G.; Rotondo, D.; Pertwee, R.G.; Heys, S.D.; Wahle, K.W. Cannabinoids and omega-3/6 endocannabinoids as cell death and anticancer modulators. Prog. Lipid Res. 2013, $52,80-109$.

40. Balvers, M.G.; Wortelboer, H.M.; Witkamp, R.F.; Verhoeckx, K.C. Liquid chromatography-tandem mass spectrometry analysis of free and esterified fatty acid $\mathrm{N}$-acyl ethanolamines in plasma and blood cells. Anal. Biochem. 2013, 434, 275-283.

41. Rovito, D.; Giordano, C.; Vizza, D.; Plastina, P.; Barone, I.; Casaburi, I.; Lanzino, M.; de Amicis, F.; Sisci, D.; Mauro, L.; et al. Omega-3 PUFA ethanolamides DHEA and EPEA induce autophagy through PPAR $\gamma$ activation in MCF-7 breast cancer cells. J. Cell. Physiol. 2013, 228, 1314-1322.

42. Brown, I.; Wahle, K.W.; Cascio, M.G.; Smoum-Jaouni. R.; Mechoulam, R.; Pertwee, R.G.; Heys, S.D. Omega-3 N-acylethanolamines are endogenously synthesised from omega-3 fatty acidsin different human prostate and breast cancer cell lines. Prostaglandins Leukot. Essent. Fat. Acids 2011, 85, 305-310. 
43. Meijerink, J.; Plastina, P.; Vincken, J.P.; Poland, M.; Attya, M.; Balvers, M.; Gruppen, H.; Gabriele, B.; Witkamp, R.F. The ethanolamide metabolite of DHA, docosahexaenoylethanolamine, shows immunomodulating effects in mouse peritoneal and RAW264.7 macrophages: Evidence for a new link between fish oil and inflammation. Br. J. Nutr. 2011, 4, 1-10.

44. Balvers, M.G.; Verhoeckx, K.C.; Plastina, P.; Wortelboer, H.M.; Meijerink, J.; Witkamp, R.F. Docosahexaenoic acid and eicosapentaenoic acid are converted by 3T3-L1 adipocytes to N-acyl ethanolamines with anti-inflammatory properties. Biochim. Biophys. Acta 2010, 1801, 1107-1114.

45. Poli, E.; Manfé, S.; Capuzzo, D.; Gava, S.; Viganò, F.; Coronella, M.L.; Gangemi, M. DHEA pre-treated patients, poor responders to a first IVF (ICSI) cycle: Clinical results. Clin. Exp. Obstet. Gynecol. 2014, 41, 5-9.

46. Hansen, H.S. Palmitoylethanolamide and other anandamide congeners. Proposed role in the diseased brain. Exp. Neurol. 2010, 224, 48-55.

47. Ho, W.S.; Barrett, D.A.; Randall, M.D. "Entourage" effects of N-palmitoylethanolamide and N-oleoylethanolamide on vasorelaxation to anandamide occur through TRPV1 receptors. Br. J. Pharmacol. 2008, 155, 837-846.

48. Costa, B.; Comelli, F.; Bettoni, I.; Colleoni, M.; Giagnoni, G. The endogenous fatty acid amide, palmitoylethanolamide, has anti-allodynic and anti-hyperalgesic effects in a murine model of neuropathic pain: Involvement of CB(1), TRPV1 and PPARgamma receptors and neurotrophic factors. Pain 2008, 139, 541-550.

49. Almási, R.; Szoke, E.; Bölcskei, K.; Varga, A.; Riedl, Z.; Sándor, Z.; Szolcsányi, J.; Petho, G. Actions of 3-methyl-N-oleoyldopamine, 4-methyl-N-oleoyldopamine and N-oleoylethanolamide on the rat TRPV1 receptor in vitro and in vivo. Life Sci. 2008, 82, 644-651.

50. Di Cesare Mannelli, L.; D’Agostino, G.; Pacini, A.; Russo, R.; Zanardelli, M.; Ghelardini, C.; Calignano, A. Palmitoylethanolamide is a disease-modifying agent in peripheral neuropathy: Pain relief and neuroprotection share a PPAR-alpha-mediated mechanism. Mediat. Inflamm. 2013, 2013, 328797, doi:10.1155/2013/328797.

51. Esposito, G.; Capoccia, E.; Turco, F.; Palumbo, I.; Lu, J.; Steardo, A.; Cuomo, R.; Sarnelli, G.; Steardo, L. Palmitoylethanolamide improves colon inflammation through an enteric glia/toll like receptor 4-dependent PPAR- $\alpha$ activation. Gut 2014, 63, 1300-1312.

52. Moriconi, A.; Cerbara, I.; Maccarrone, M.; Topai, A. GPR55: Current knowledge and future perspectives of a purported "Type-3” cannabinoid receptor. Curr. Med. Chem. 2010, 17, 1411-1429.

53. Overton, H.A.; Fyfe, M.C.; Reynet, C. GPR119, a novel G protein-coupled receptor target for the treatment of type 2 diabetes and obesity. Br. J. Pharmacol. 2008, 153, S76-S81.

54. Cravatt, B.F.; Giang, D.K.; Mayfield, S.P.; Boger, D.L.; Lerner, R.A.; Gilula, N.B. Molecular characterization of an enzyme that degrades neuromodulatory fatty-acid amides. Nature 1996, 384, 83-87.

55. Ueda, N.; Tsuboi, K.; Uyama, T. N-acylethanolamine metabolism with special reference to N-acylethanolamine-hydrolyzing acid amidase (NAAA). Prog. Lipid Res. 2010, 49, 299-315.

56. Artmann, A.; Petersen, G.; Hellgren, L.I.; Boberg, J.; Skonberg C.; Nellemann, C.; Hansen, S.H.; Hansen, H.S. Influence of dietary fatty acids on endocannabinoid and N-acylethanolamine levels in rat brain, liver and small intestine. Biochim. Biophys. Acta 2008, 1781, 200-212. 
57. Lucanic, M.; Held, J.M.; Vantipalli, M.C.; Klang, I.M.; Graham, J.B.; Gibson, B.W.; Lithgow, G.J.; Gill, M.S. $N$-acylethanolamine signalling mediates the effect of diet on lifespan in Caenorhabditis elegans. Nature 2011, 473, 226-229.

58. Brown, I.; Cascio, M.G.; Wahle, K.W.; Smoum, R.; Mechoulam, R.; Ross, R.A.; Pertwee, R.G.; Heys, S.D. Cannabinoid receptor-dependent and -independent anti-proliferative effects of omega-3 ethanolamides in androgen receptor-positive and -negative prostate cancer cell lines. Carcinogenesis 2010, 31, 1584-1591.

59. Di Patrizio, N.V.; Piomelli, D. The thrifty lipids: Endocannabinoids and the neural control of energy conservation. Trends Neurosci. 2012, 35, 403-411.

60. Maccarrone, M. Endocannabinoids: Friends and foes of reproduction. Prog. Lipid Res. 2009, 48, 344-354.

61. Maione, S.; Costa, B.; di Marzo, V. Endocannabinoids: A unique opportunity to develop multitarget analgesics. Pain 2013, 154, S87-S93.

62. Galve-Roperh, I.; Chiurchiù, V.; Díaz-Alonso, J.; Bari, M.; Guzmán, M.; Maccarrone, M. Cannabinoid receptor signaling in progenitor/stem cell proliferation and differentiation. Prog. Lipid Res. 2013, 52, 633-650.

63. Pacher, P.; Kunos, G. Modulating the endocannabinoid system in human health and disease-Successes and failures. FEBS J. 2013, 280, 1918-1943.

64. Bisogno, T.; Maccarrone, M. Latest advances in the discovery of fatty acid amide hydrolase inhibitors. Expert Opin. Drug Discov. 2013, 8, 509-522.

65. Gaetani, S.; Kaye, W.H.; Cuomo, V.; Piomelli, D. Role of endocannabinoids and their analogues in obesity and eating disorders. Eat. Weight Disord. 2008, 13, e42-e46.

66. Maccarrone, M.; Bernardi, G.; Agrò, A.F.; Centonze, D. Cannabinoid receptor signalling in neurodegenerative diseases: A potential role for membrane fluidity disturbance. Br. J. Pharmacol. 2011, 163, 1379-1390.

67. Pertwee, R.G. Targeting the endocannabinoid system with cannabinoid receptor agonists: Pharmacological strategies and therapeutic possibilities. Philos. Trans. R. Soc. Lond. B Biol. Sci. 2012, 367, 3353-3363.

68. McPartland, J.M.; Guy, G.; Di Marzo, V. Care and feeding of the endocannabinoid system: A systematic review of potential clinical interventions that upregulate the endocannabinoid system. PLoS One 2014, 9, e89566.

69. Di Marzo, V.; Petrosino, S. Endocannabinoids and the regulation of their levels in health and disease. Curr. Opin. Lipidol. 2007, 18, 129-140.

70. Katona, I.; Freund, T.F. Endocannabinoid signaling as a synaptic circuit breaker in neurological disease. Nat. Med. 2008, 14, 923-930.

71. Schlosburg, J.E.; Blankman, J.L.; Long, J.Z.; Nomura, D.K.; Pan, B.; Kinsey, S.G.; Nguyen, P.T.; Ramesh, D.; Booker, L.; Burston, J.J.; et al. Chronic monoacylglycerol lipase blockade causes functional antagonism of the endocannabinoid system. Nat. Neurosci. 2010, 13, 1113-1119.

72. Zoerner, A.A.; Gutzki, F.M.; Batkai, S.; May, M.; Rakers, C.; Engeli, S.; Jordan, J.; Tsikas, D. Quantification of endocannabinoids in biological systems by chromatography and mass spectrometry: A comprehensive review from an analytical and biological perspective. Biochim. Biophys. Acta 2011, 1811, 706-723. 
73. Alger, B.E.; Kim, J. Supply and demand for endocannabinoids. Trends Neurosci. 2011, 34, 304-315.

74. Di Marzo, V.; de Petrocellis, L. Why do cannabinoid receptors have more than one endogenous ligand? Philos. Trans. R. Soc. Lond. B Biol. Sci. 2012, 367, 3216-3228.

75. Jung, K.M.; Clapper, J.R.; Fu, J.; D’Agostino, G.; Guijarro, A.; Thongkham, D.; Avanesian, A.; Astarita, G.; Di Patrizio, N.V.; Frontini, A.; et al. 2-arachidonoylglycerol signaling in forebrain regulates systemic energy metabolism. Cell Metab. 2012, 15, 299-310.

76. Sugiura, T.; Kobayashi, Y.; Oka, S.; Waku, K. Biosynthesis and degradation of anandamide and 2-arachidonoylglycerol and their possible physiological significance. Prostaglandins Leukot. Essent. Fat. Acids 2002, 66, 173-192.

77. Elphick, M.R. The evolution and comparative neurobiology of endocannabinoid signalling. Philos. Trans. R. Soc. Lond. B Biol. Sci. 2012, 367, 3201-3215.

78. Wilson, R.I.; Nicoll, R.A. Endogenous cannabinoids mediate retrograde signalling at hippocampal synapses. Nature 2001, 410, 588-592.

79. Vaughan, C.W.; Christie, M.J. Retrograde signalling by endocannabinoids. Handb. Exp. Pharmacol. 2005, 168, 367-383.

80. Buczynski, M.W.; Parsons, L.H.B. Quantification of brain endocannabinoid levels: Methods, interpretations and pitfalls. J. Pharmacol. 2010, 160, 423-442.

81. Maccarrone, M.; Gasperi, V.; Catani, M.V.; Diep, T.A.; Dainese, E.; Hansen, H.S.; Avigliano, L. The endocannabinoid system and its relevance for nutrition. Annu. Rev. Nutr. 2010, 30, 423-440.

82. Kleberg, K.; Hassing, H.A.; Hansen, H.S. Classical endocannabinoid-like compounds and their regulation by nutrients. Biofactors 2014, doi:10.1002/biof.1158.

83. Engeli, S.; Lehmann, A.C.; Kaminski, J.; Haas, V.; Janke, J.; Zoerner, A.A.; Luft, F.C.; Tsikas, D.; Jordan, J. Influence of dietary fat intake on the endocannabinoid system in lean and obese subjects. Obesity 2014, 22, E70-E76.

84. Lafourcade, M.; Larrieu, T.; Mato, S.; Duffaud, A.; Sepers, M.; Matias, I.; de Smedt-Peyrusse, V.; Labrousse, V.F.; Bretillon, L.; Matute, C.; et al. Nutritional omega-3 deficiency abolishes endocannabinoid-mediated neuronal functions. Nat. Neurosci. 2011, 14, 345-350.

85. Blankman, J.L.; Cravatt B.F. Chemical probes of endocannabinoid metabolism. Pharmacol. Rev. 2013, 65, 849-871.

86. Huang, S.M.; Bisogno, T.; Trevisani, M.; Al-Hayani, A.; de Petrocellis, L.; Fezza, F.; Tognetto, M.; Petros, T.J.; Krey, J.F.; Chu, C.J.; et al. An endogenous capsaicin-like substance with high potency at recombinant and native vanilloid VR1 receptors. Proc. Natl. Acad. Sci. USA 2002, 99 , 8400-8405.

87. Balvers, M.G.; Verhoeckx, K.C.; Witkamp, R.F. Development and validation of a quantitative method for the determination of 12 endocannabinoids and related compounds in human plasma using liquid chromatography-tandem mass spectrometry. J. Chromatogr. B Anal. Technol. Biomed. Life Sci. 2009, 877, 14-15.

88. Fezza, F.; Bisogno, T.; Minassi, A.; Appendino, G.; Mechoulam, R.; Di Marzo, V. Noladin ether, a putative novel endocannabinoid: Inactivation mechanisms and a sensitive method for its quantification in rat tissues. FEBS Lett. 2002, 513, 294-298.

89. Sun, Y.; Alexander, S.P.; Kendall, D.A.; Bennett, A.J. Cannabinoids and PPARalpha signalling. Biochem. Soc. Trans. 2006, 34, 1095-1097. 
90. Sun, Y.; Alexander, S.P.; Garle, M.J. Cannabinoid activation of PPAR alpha; a novel neuroprotective mechanism. Br. J. Pharmacol. 2007, 152, 734-743.

91. Sharir, H.; Console-Bram, L.; Mundy, C.; Popoff, S.N.; Kapur, A.; Abood, M.E. The endocannabinoids anandamide and virodhamine modulate the activity of the candidate cannabinoid receptor GPR55. J. Neuroimmune Pharmacol. 2012, 7, 856-865.

92. De Petrocellis, L.; Di Marzo, V. Role of endocannabinoids and endovanilloids in $\mathrm{Ca}^{2+}$ signalling. Cell Calcium 2009, 45, 611-624.

93. Hu, S.S.; Bradshaw, H.B.; Benton, V.M.; Chen, J.S.; Huang, S.M.; Minassi, A.; Bisogno, T.; Masuda, K.; Tan, B.; Roskoski, R., Jr.; et al. The biosynthesis of N-arachidonoyl dopamine (NADA), a putative endocannabinoid and endovanilloid, via conjugation of arachidonic acid with dopamine. Prostaglandins Leukot. Essent. Fat. Acids 2009, 81, 291-301.

94. Lehtonen, M.; Storvik, M.; Malinen, H.; Hyytiä, P.; Lakso, M.; Auriola, S.; Wong, G.; Callaway, J.C. Determination of endocannabinoids in nematodes and human brain tissue by liquid chromatography electrospray ionization tandem mass spectrometry. J. Chromatogr. B Anal. Technol. Biomed. Life Sci. 2011, 879, 677-694.

95. Bystrowska, B.; Smaga, I.; Tyszka-Czochara, M.; Filip, M. Troubleshooting in LC-MS/MS method for determining endocannabinoid and endocannabinoid-like molecules in rat brain structures applied to assessing the brain endocannabinoid/endovanilloid system significance. Toxicol. Mech. Methods 2014, 24, 315-322.

96. Burr, G.O.; Burr, M.M. Nutrition classics from The Journal of Biological Chemistry 82:345-67, 1929. A new deficiency disease produced by the rigid exclusion of fat from the diet. Nutr. Rev. 1973, 31, 248-249.

97. Barrett, S.J. The role of omega-3 polyunsaturated fatty acids in cardiovascular health. Altern. Ther. Health Med. 2013, 1, 26-30.

98. Maskrey, B.H.; Megson, I.L.; Rossi, A.G.; Whitfield, P.D. Emerging importance of omega-3 fatty acids in the innate immune response: Molecular mechanisms and lipidomic strategies for their analysis. Mol. Nutr. Food Res. 2013, 57, 1390-1400.

99. Peskin, B.S. Why fish oil fails: A comprehensive 21 st century lipids-based physiologic analysis. J. Lipids 2014, 2014, 495761.

100. Morales-Lázaro, S.L.; Simon, S.A.; Rosenbaum, T. The role of endogenous molecules in modulating pain through transient receptor potential vanilloid 1 (TRPV1). J. Physiol. 2013, 591, 3109-3121.

101. Park, C.K.; Xu, Z.Z.; Liu, T.; Serhan, C.N.; Ji, R.R. Resolvin D2 is a potent endogenous inhibitor for transient receptor potential subtype V1/A1, inflammatory pain, and spinal cord synaptic plasticity in mice: Distinct roles of resolvin D1, D2, and E1. J. Neurosci. 2011, 31, 18433-18438.

102. Weylandt, K.H.; Chiu, C.Y.; Gomolka, B.; Waechter, S.F.; Wiedenmann, B. Omega-3 fatty acids and their lipid mediators: Towards an understanding of resolvin and protectin formation. Prostaglandins Other Lipid Mediat. 2012, 97, 73-82.

103. Russell, C.D.; Schwarze, J. The role of pro-resolution lipid mediators in infectious disease. Immunology 2014, 141, 166-173. 
104. Citraro, R.; Russo, E.; Scicchitano, F.; van Rijn, C.M.; Cosco, D.; Avagliano, C.; Russo, R.; D'Agostino, G.; Petrosino, S.; Guida, F.; et al. Antiepileptic action of N-palmitoylethanolamine through $\mathrm{CB}_{1}$ and PPAR- $\alpha$ receptor activation in a genetic model of absence epilepsy. Neuropharmacology 2013, 69, 115-126.

105. Esposito, E.; Impellizzeri, D.; Mazzon, E.; Paterniti, I.; Cuzzocrea, S. Neuroprotective activities of palmitoylethanolamide in an animal model of Parkinson's disease. PLoS One 2012, 7, e41880.

106. Fu, J.; Bottegoni, G.; Sasso, O.; Bertorelli, R.; Rocchia, W.; Masetti, M.; Guijarro, A.; Lodola, A.; Armirotti, A.; Garau, G.; et al. A catalytically silent FAAH-1 variant drives anandamide transport in neurons. Nat. Neurosci. 2011, 15, 64-69.

107. Guzmán, M.; Lo Verme, J.; Fu, J.; Oveisi, F.; Blázquez, C.; Piomelli, D. Oleoylethanolamide stimulates lipolysis by activating the nuclear receptor peroxisome proliferator-activated receptor alpha (PPAR-alpha). J. Biol. Chem. 2004, 279, 27849-27854.

108. Suardíaz, M.; Estivill-Torrús, G.; Goicoechea, C.; Bilbao, A.; Rodríguez de Fonseca, F. Analgesic properties of oleoylethanolamide (OEA) in visceral and inflammatory pain. Pain 2007, 133, 99-110.

109. Moran, B.M.; Abdel-Wahab, Y.H.; Flatt, P.R.; McKillop, A.M. Activation of GPR119 by fatty acid agonists augments insulin release from clonal $\beta$-cells and isolated pancreatic islets and improves glucose tolerance in mice. Biol. Chem. 2014, 395, 453-464.

110. Hansen, H.S.; Rosenkilde, M.M.; Holst, J.J.; Schwartz, T.W. GPR119 as a fat sensor. Trends Pharmacol. Sci. 2012, 33, 374-381.

111. Lan, H.; Vassileva, G.; Corona, A.; Liu, L.; Baker, H.; Golovko, A.; Abbondanzo, S.J.; Hu, W.; Yang, S.; Ning, Y.; et al. GPR119 is required for physiological regulation of glucagon-like peptide-1 secretion but not for metabolic homeostasis. J. Endocrinol. 2009, 201, 219-230.

112. Maccarrone, M.; Cartoni, A.; Parolaro, D.; Margonelli, A.; Massi, P.; Bari, M.; Battista, N.; Finazzi-Agrò, A. Cannabimimetic activity, binding, and degradation of stearoylethanolamide within the mouse central nervous system. Mol. Cell. Neurosci. 2002, 21, 126-140.

113. Dalle Carbonare, M.; Del Giudice, E.; Stecca, A.; Colavito, D.; Fabris, M.; D’Arrigo, A.; Bernardini, D.; Dam, M.; Leon, A. A saturated N-acylethanolamine other than N-palmitoyl ethanolamine with anti-inflammatory properties: A neglected story. J. Neuroendocrinol. 2008, 1 , 26-34.

114. Ghafouri, N.; Ghafouri, B.; Larsson, B.; Stensson, N.; Fowler, C.J.; Gerdle, B. Palmitoylethanolamide and stearoylethanolamide levels in the interstitium of the trapezius muscle of women with chronic widespread pain and chronic neck-shoulder pain correlate with pain intensity and sensitivity. Pain 2013, 154, 1649-1658.

115. Han, B.; Wright, R.; Kirchhoff, A.M.; Chester, J.A.; Cooper, B.R.; Davisson, V.J.; Barker, E. Quantitative LC-MS/MS analysis of arachidonoyl amino acids in mouse brain with treatment of FAAH inhibitor. Anal. Biochem. 2013, 432, 74-81.

116. Ottria, R.; Ravelli, A.; Gigli, F.; Ciuffreda, P. Simultaneous ultra-high performance liquid chromathograpy-electrospray ionization-quadrupole-time of flight mass spectrometry quantification of endogenous anandamide and related $\mathrm{N}$-acylethanolamides in bio-matrices. J. Chromatogr. B Anal. Technol. Biomed. Life Sci. 2014, 958, 83-89. 
117. Terrazzino, S.; Berto, F.; Dalle Carbonare, M.; Fabris, M.; Guiotto, A.; Bernardini, D.; Leon, A. Stearoylethanolamide exerts anorexic effects in mice via down-regulation of liver stearoyl-coenzyme A desaturase-1 mRNA expression. FASEB J. 2004, 18, 1580-1582.

118. Huang, S.M.; Bisogno, T.; Petros, T.J.; Chang, S.Y.; Zavitsanos, P.A.; Zipkin, R.E.; Sivakumar, R.; Coop, A.; Maeda, D.Y.; De Petrocellis, L.; et al. Identification of a new class of molecules, the arachidonyl amino acids, and characterization of one member that inhibits pain. J. Biol. Chem. 2001, 276, 42639-42644.

119. Milman, G.; Maor, Y.; Abu-Lafi, S.; Horowitz, M.; Gallily, R.; Batkai, S.; Mo, F.M.; Offertaler, L.; Pacher, P.; Kunos, G.; et al. N-arachidonoyl L-serine, an endocannabinoid-like brain constituent with vasodilatory properties. Proc. Natl. Acad. Sci. USA 2006, 103, 2428-2433.

120. Hanuš, L.; Shohami, E.; Bab, I.; Mechoulam, R. N-Acyl amino acids and their impact on biological processes. Biofactors 2014, doi:10.1002/biof.1166.

121. Kohno, M.; Hasegawa, H.; Inoue, A.; Muraoka, M.; Miyazaki, T.; Oka, K.; Yasukawa, M. Identification of $\mathrm{N}$-arachidonylglycine as the endogenous ligand for orphan G-protein-coupled receptor GPR18. Biochem. Biophys. Res. Commun. 2006, 347, 827-832.

122. McHugh, D.; Roskowski, D.; Xie, S.; Bradshaw, H.B. $\Delta(9)$-THC and N-arachidonoyl glycine regulate BV-2 microglial morphology and cytokine release plasticity: Implications for signaling at GPR18. Front. Pharmacol. 2014, 4, 162, doi:10.3389/fphar.2013.00162.

123. Penumarti, A.; Abdel-Rahman, A.A. The novel endocannabinoid receptor GPR18 is expressed in the rostral ventrolateral medulla and exerts tonic restraining influence on blood pressure. J. Pharmacol. Exp. Ther. 2014, 349, 29-38.

124. Oh, D.Y.; Yoon, J.M.; Moon, M.J.; Hwang, J.I.; Choe, H.; Lee, J.Y.; Kim, J.I.; Kim, S.; Rhim, H.; O’Dell, D.K.; et al. Identification of farnesyl pyrophosphate and N-arachidonylglycine as endogenous ligands for GPR92. J. Biol. Chem. 2008, 283, 21054-21064.

125. Cascio, M.G.; Minassi, A.; Ligresti, A.; Appendino, G.; Burstein, S.; Di Marzo, V. A structure-activity relationship study on $\mathrm{N}$-arachidonoyl-amino acids as possible endogenous inhibitors of fatty acid amide hydrolase. Biochem. Biophys. Res. Commun. 2004, 314, 192-196.

126. Cohen-Yeshurun, A.; Willner, D.; Trembovler, V.; Alexandrovich, A.; Mechoulam, R.; Shohami, E.; Leker, R.R. $N$-arachidonoyl-L-serine (AraS) possesses proneurogenic properties in vitro and in vivo after traumatic brain injury. J. Cereb. Blood Flow Metab. 2013, 33, 1242-1250.

127. Hesselink, J.M.; Hekker, T.A. Therapeutic utility of palmitoylethanolamide in the treatment of neuropathic pain associated with various pathological conditions: A case series. J. Pain Res. 2012, 5, 437-442.

128. Di Marzo, V.; Ligresti, A.; Morera, E.; Nalli, M.; Ortar, G. The anandamide membrane transporter. Structure-activity relationships of anandamide and oleoylethanolamine analogs with phenyl rings in the polar head group region. Bioorg. Med. Chem. 2004, 12, 5161-5169.

129. Min, R.; di Marzo, V.; Mansvelder, H.D. DAG lipase involvement in depolarization-induced suppression of inhibition: Does endocannabinoid biosynthesis always meet the demand? Neuroscientist 2010, 16, 608-613.

130. Di Marzo, V. Endocannabinoid signaling in the brain: Biosynthetic mechanisms in the limelight. Nat. Neurosci. 2011, 14, 9-15. 
131. Tsuboi, K.; Okamoto, Y.; Ikematsu, N.; Inoue, M.; Shimizu, Y.; Uyama, T.; Wang, J.; Deutsch, D.G.; Burns, M.P.; Ulloa, N.M.; et al. Enzymatic formation of N-acylethanolamines from $\mathrm{N}$-acylethanolamine plasmalogen through $\mathrm{N}$-acylphosphatidylethanolamine-hydrolyzing phospholipase D-dependent and -independent pathways. Biochim. Biophys. Acta 2011, 1811, $565-577$.

132. Fukami, K.; Inanobe, S.; Kanemaru, K.; Nakamura, Y. Phospholipase C is a key enzyme regulating intracellular calcium and modulating the phosphoinositide balance. Prog. Lipid Res. 2010, 49, 429-437.

133. Berdyshev, E.V.; Schmid, P.C.; Krebsbach, R.J.; Schmid, H.H. Activation of PAF receptors results in enhanced synthesis of 2-arachidonoylglycerol (2-AG) in immune cells. FASEB J. 2001, $15,2171-2178$.

134. Oka, S.; Yanagimoto, S.; Ikeda, S.; Gokoh, M.; Kishimoto, S.; Waku, K.; Ishima, Y.; Sugiura, T. Evidence for the involvement of the cannabinoid $\mathrm{CB}_{2}$ receptor and its endogenous ligand 2-arachidonoylglycerol in 12-O-tetradecanoylphorbol-13-acetate-induced acute inflammation in mouse ear. J. Biol. Chem. 2005, 280, 18488-18497.

135. Gao, Y.; Vasilyev, D.V.; Goncalves, M.B.; Howell, F.V.; Hobbs, C.; Reisenberg, M.; Shen, R.; Zhang, M.Y.; Strassle, B.W.; Lu, P.; et al. Loss of retrograde endocannabinoid signaling and reduced adult neurogenesis in diacylglycerol lipase knock-out mice. J. Neurosci. 2010, 30, 2017-2024.

136. Tanimura, A.; Yamazaki, M.; Hashimotodani, Y.; Uchigashima, M.; Kawata, S.; Abe, M.; Kita, Y.; Hashimoto, K.; Shimizu, T.; Watanabe, M.; et al. The endocannabinoid 2-arachidonoylglycerol produced by diacylglycerol lipase alpha mediates retrograde suppression of synaptic transmission. Neuron 2010, 65, 320-327.

137. Maccarrone, M.; Rossi, S.; Bari, M.; de Chiara, V.; Fezza, F.; Musella, A.; Gasperi, V.; Prosperetti, C.; Bernardi, G.; Finazzi-Agrò, A.; et al. Anandamide inhibits metabolism and physiological actions of 2-arachidonoylglycerol in the striatum. Nat. Neurosci. 2008, 11, 152-159.

138. Shonesy, B.C.; Wang, X.; Rose, K.L.; Ramikie, T.S.; Cavener, V.S.; Rentz, T.; Baucum, A.J.; Jalan-Sakrikar, N.; Mackie, K.; Winder, D.G.; et al. CaMKII regulates diacylglycerol lipase- $\alpha$ and striatal endocannabinoid signaling. Nat. Neurosci. 2013, 16, 456-463.

139. Price, T.J.; Jeske, N.A.; Flores, C.M.; Hargreaves, K.M. Pharmacological interactions between calcium/calmodulin-dependent kinase II alpha and TRPV1 receptors in rat trigeminal sensory neurons. Neurosci. Lett. 2005, 389, 94-98.

140. Di Marzo, V.; Fontana, A.; Cadas, H.; Schinelli, S.; Cimino, G.; Schwartz, J.C.; Piomelli, D. Formation and inactivation of endogenous cannabinoid anandamide in central neurons. Nature 1994, 372, 686-691.

141. Fezza, F.; Oddi, S.; Di Tommaso, M.; de Simone, C.; Rapino, C.; Pasquariello, N.; Dainese, E.; Finazzi-Agrò, A.; Maccarrone, M. Characterization of biotin-anandamide, a novel tool for the visualization of anandamide accumulation. J. Lipid Res. 2008, 49, 1216-1223.

142. Hillard, C.; Jarrahian, A. The movement of N-arachidonoylethanolamine (anandamide) across cellular membranes. Chem. Phys. Lipids 2000, 108, 123-134.

143. Fowler, C.J. Transport of endocannabinoids across the plasma membrane and within the cell. FEBS J. 2013, 3280, 1895-1904. 
144. Deutsch, D.G.; Glaser, S.T.; Howell, J.M.; Kunz, J.S.; Puffenbarger, R.A.; Hillard, C.J.; Abumrad, N. The cellular uptake of anandamide is coupled to its breakdown by fatty-acid amide hydrolase. J. Biol. Chem. 2001, 276, 6967-6973.

145. Kaczocha, M.; Hermann, A.; Glaser, S.T.; Bojesen, I.N.; Deutsch, D.G. Anandamide uptake is consistent with rate-limited diffusion and is regulated by the degree of its hydrolysis by fatty acid amide hydrolase. J. Biol. Chem. 2006, 281, 9066-9075.

146. Oddi, S.; Fezza, F.; Pasquariello, N.; de Simone, C.; Rapino, C.; Dainese, E.; Finazzi-Agrò, A.; Maccarrone, M. Evidence for the intracellular accumulation of anandamide in adiposomes. Cell. Mol. Life Sci. 2008, 65, 840-850.

147. Di Pasquale, E.; Chahinian, H.; Sanchez, P.; Fantini, J. The insertion and transport of anandamide in synthetic lipid membranes are both cholesterol-dependent. PLoS One 2009, 4, e4989, doi:10.1371/journal.pone.0004989.

148. Oddi, S.; Fezza, F.; Pasquariello, N.; D’Agostino, A.; Catanzaro, G.; De Simone, C.; Rapino, C.; Finazzi-Agrò, A.; Maccarrone, M. Molecular identification of albumin and Hsp70 as cytosolic 12 anandamide-binding proteins. Chem. Biol. 2009, 16, 624-632.

149. Kaczocha, M.; Glaser, S.T.; Deutsch, D.G. Identification of intracellular carriers for the endocannabinoid anandamide. Proc. Natl. Acad. Sci. USA 2009, 106, 6375-6380.

150. Kaczocha, M.; Vivieca, S.; Sun, J.; Glaser, S.T.; Deutsch, D.G. Fatty acid-binding proteins transport $\mathrm{N}$-acylethanolamines to nuclear receptors and are targets of endocannabinoid transport inhibitors. J. Biol. Chem. 2012, 287, 3415-3424.

151. Chicca, A.; Marazzi, J.; Nicolussi, S.; Gertsch, J. Evidence for bidirectional endocannabinoid transport across cell membranes. J. Biol. Chem. 2012, 287, 34660-34682.

152. Maccarrone, M.; Bari, M.; Battista, N.; Finazzi-Agrò, A. Estrogen stimulates arachidonoylethanolamide release from human endothelial cells and platelet activation. Blood 2002 100, 4040-4048.

153. Hillard, C.J.; Jarrahian, A. Accumulation of anandamide: Evidence for cellular diversity. Neuropharmacology 2005, 48, 1072-1078.

154. Piomelli, D.; Beltramo, M.; Glasnapp, S.; Lin, S.Y.; Goutopoulos, A.; Xie, X.Q.; Makriyannis, A. Structural determinants for recognition and translocation by the anandamide transporter. Proc. Natl. Acad. Sci. USA 1999, 96, 5802-5807.

155. Bisogno, T.; Maccarrone, M.; de Petrocellis, L.; Jarrahian, A.; Finazzi-Agrò, A.; Hillard, C.; di Marzo, V. The uptake by cells of 2-arachidonoylglycerol, an endogenous agonist of cannabinoid receptors. Eur. J. Biochem. 2001, 268, 1982-1989.

156. Hermann, A.; Kaczocha, M.; Deutsch, D.G. 2-Arachidonoylglycerol (2-AG) membrane transport: History and outlook. AAPS J. 2006, 8, 409-412.

157. Ehehalt, R.; Füllekrug, J.; Pohl, J.; Ring, A.; Herrmann, T.; Stremmel, W. Translocation of long chain fatty acids across the plasma membrane-Lipid rafts and fatty acid transport proteins. Mol. Cell. Biochem. 2006, 284, 135-140.

158. Fezza, F.; de Simone, C.; Amadio, D.; Maccarrone, M. Fatty acid amide hydrolase: A gatekeeper of the endocannabinoid system. Subcell. Biochem. 2008, 49, 101-132. 
159. McKinney, M.K.; Cravatt, B.F. Evidence for distinct roles in catalysis for residues of the serine-serine-lysine catalytic triad of fatty acid amide hydrolase. J. Biol. Chem. 2003, 278, 37393-37399.

160. Kaczocha, M.; Glaser, S.T.; Chae, J.; Brown, D.A.; Deutsch, D.G. Lipid droplets are novel sites of N-acylethanolamine inactivation by fatty acid amide hydrolase-2. J. Biol. Chem. 2010, 285, 2796-2806.

161. Ponzano, S.; Bertozzi, F.; Mengatto, L.; Dionisi, M.; Armirotti, A.; Romeo, E.; Berteotti, A.; Fiorelli, C.; Tarozzo, G.; Reggiani, A.; et al. Synthesis and structure-activity relationship (SAR) of 2-methyl-4-oxo-3-oxetanylcarbamic acid esters, a class of potent N-acylethanolamine acid amidase (NAAA) inhibitors. J. Med. Chem. 2013, 56, 6917-6934.

162. Vitale, R.; Ottonello, G.; Petracca, R.; Bertozzi, S.M.; Ponzano, S.; Armirotti, A.; Berteotti, A.; Dionisi, M.; Cavalli, A.; Piomelli, D.; et al. Synthesis, structure-activity, and structure-stability relationships of 2-substituted-N-(4-oxo-3-oxetanyl) N-acylethanolamine acid amidase (NAAA) inhibitors. Chem. Med. Chem. 2014, 9, 323-336.

163. Cravatt, B.F.; Demarest, K.; Patricelli, M.P.; Bracey, M.H.; Giang, D.K.; Martin, B.R.; Lichtman, A.H. Supersensitivity to anandamide and enhanced endogenous cannabinoid signaling in mice lacking fatty acid amide hydrolase. Proc. Natl. Acad. Sci. USA 2001, 98, 9371-9376.

164. Pan, B.; Wang, W.; Zhong, P.; Blankman, J.L.; Cravatt, B.F.; Liu Q.S. Alterations of endocannabinoid signaling, synaptic plasticity, learning, and memory in monoacylglycerol lipase knock-out mice. J. Neurosci. 2011, 31, 13420-13430.

165. Di Marzo, V.; Maccarrone, M. FAAH and anandamide: Is 2-AG really the odd one out? Trends Pharmacol. Sci. 2008, 29, 229-233.

166. Long, J.Z.; Li, W.; Booker, L.; Burston, J.J.; Kinsey, S.G.; Schlosburg, J.E.; Pavón, F.J.; Serrano, A.M.; Selley, D.E.; Parsons, L.H.; et al. Selective blockade of 2-arachidonoylglycerol hydrolysis produces cannabinoid behavioral effects. Nat. Chem. Biol. 2009, 5, 37-44.

167. Dinh, T.P.; Carpenter, D.; Leslie, F.M.; Freund, T.F.; Katona, I.; Sensi, S.L.; Kathuria, S.; Piomelli, D. Brain monoglyceride lipase participating in endocannabinoid inactivation. Proc. Natl. Acad. Sci. USA 2002, 99, 10819-10824.

168. Ho, S.Y.; Delgado, L.; Storch, J. Monoacylglycerol metabolism in human intestinal Caco-2 cells: Evidence for metabolic compartmentation and hydrolysis. J. Biol. Chem. 2002, 277, 1816-1823.

169. Karlsson, M.; Contreras, J.A.; Hellman, U.; Tornqvist, H.; Holm, C. cDNA cloning, tissue distribution, and identification of the catalytic triad of monoglyceride lipase. Evolutionary relationship to esterases, lysophospholipases, and haloperoxidases. Biol. Chem. 1997, 272, 27218-27223.

170. Karlsson, M.; Reue, K.; Xia, Y.R.; Lusis, A.J.; Langin, D.; Tornqvist, H.; Holm, C. Exon-intron organization and chromosomal localization of the mouse monoglyceride lipase gene. Gene 2001, 272, 11-18.

171. Nomura, D.K.; Long, J.Z.; Niessen, S.; Hoover, H.S.; Ng, S.W.; Cravatt, B.F. Monoacylglycerol lipase regulates a fatty acid network that promotes cancer pathogenesis. Cell 2010, 140, 49-61.

172. Galli, G.G.; Multhaupt, H.A.; Carrara, M.; de Lichtenberg, K.H.; Christensen, I.B.; Linnemann, D.; Santoni-Rugiu, E.; Calogero, R.A.; Lund, A.H. Prdm5 suppresses Apc(Min)-driven intestinal adenomas and regulates monoacylglycerol lipase expression. Oncogene 2014, 33, 3342-3350. 
173. Qin, H.; Ruan, Z.H. The Role of Monoacylglycerol Lipase (MAGL) in the Cancer Progress. Cell Biochem. Biophys. 2014, 70, 33-36.

174. Savinainen, J.R.; Saario, S.M.; Laitinen, J.T. The serine hydrolases MAGL, ABHD6 and ABHD12 as guardians of 2-arachidonoylglycerol signalling through cannabinoid receptors. Acta Physiol. 2012, 204, 267-276.

175. Tchantchou, F.; Zhang, Y. Selective inhibition of alpha/beta-hydrolase domain 6 attenuates neurodegeneration, alleviates blood brain barrier breakdown, and improves functional recovery in a mouse model of traumatic brain injury. J. Neurotrauma 2013, 30, 565-79.

176. Alhouayek, M.; Masquelier, J.; Cani, P.D.; Lambert, D.M.; Muccioli, G.G. Implication of the anti-inflammatory bioactive lipid prostaglandin D2-glycerol ester in the control of macrophage activation and inflammation by ABHD6. Proc. Natl. Acad. Sci. USA 2013, 110, 17558-17563.

177. Fiskerstrand, T.; H'mida-Ben Brahim, D.; Johansson, S.; M'zahem, A.; Haukanes, B.I.; Drouot, N.; Zimmermann, J.; Cole, A.J.; Vedeler, C.; Bredrup, C.; et al. Mutations in ABHD12 cause the neurodegenerative disease PHARC: An inborn error of endocannabinoid metabolism. Am. J. Hum. Genet. 2010, 87, 410-417.

178. Blankman, J.L.; Long, J.Z.; Trauger, S.A.; Siuzdak, G.; Cravatt, B.F. ABHD12 controls brain lysophosphatidylserine pathways that are deregulated in a murine model of the neurodegenerative disease PHARC. Proc. Natl. Acad. Sci. USA 2013, 110, 1500-1505.

179. Kozak, K.R.; Marnett, L.J. Oxidative metabolism of endocannabinoids. Prostaglandins Leukot. Essent. Fat. Acids 2002, 66, 211-220.

180. McHugh, D.; McMaster, R.S.; Pertwee, R.G.; Roy, S.; Mahadevan, A.; Razdan, R.K.; Ross, R.A. Novel compounds that interact with both leukotriene B4 receptors and vanilloid TRPV1 receptors. J. Pharmacol. Exp. Ther. 2006, 316, 955-965.

181. Starowicz, K.; Przewlocka, B. Modulation of neuropathic-pain-related behaviour by the spinal endocannabinoid/endovanilloid system. Philos. Trans. R. Soc. Lond. B Biol. Sci. 2012, 367, 3286-3299.

182. Amadio, D.; Fezza, F.; Catanzaro, G.; Incani, O.; van Zadelhoff, G.; Finazzi Agrò, A.; Maccarrone, M. Methylation and acetylation of 15-hydroxyanandamide modulate its interaction with the endocannabinoid system. Biochimie 2010, 92, 378-387.

183. Dainese, E.; Sabatucci, A.; Angelucci, C.B.; Barsacchi, D.; Chiarini, M.; Maccarrone, M. Impact of embedded endocannabinoids and their oxygenation by lipoxygenase on membraneproperties. ACS Chem. Neurosci. 2012, 3, 386-392.

184. Wong-Ekkabut, J.; Xu, Z.; Triampo, W.; Tang, I.M.; Tieleman, D.P.; Monticelli, L. Effect of lipid peroxidation on the properties of lipid bilayers: A molecular dynamics study. Biophys. J. 2007, 93, 4225-4236.

185. Yang, R.; Fredman, G.; Krishnamoorthy, S.; Agrawal, N.; Irimia, D.; Piomelli, D.; Serhan, C.N. Decoding functional metabolomics with docosahexaenoyl ethanolamide (DHEA) identifies novel bioactive signals. J. Biol. Chem. 2011, 286, 31532-31541.

186. Prusakiewicz, J.J.; Turman, M.V.; Vila, A.; Ball, H.L.; Al-Mestarihi, A.H.; Di Marzo, V.; Marnett, L.J. Oxidative metabolism of lipoamino acids and vanilloids by lipoxygenases and cyclooxygenases. Arch. Biochem. Biophys. 2007, 464, 260-268. 
187. Turman, M.V.; Kingsley, P.J.; Rouzer, C.A.; Cravatt, B.F.; Marnett, L.J. Oxidative metabolism of a fatty acid amide hydrolase-regulated lipid, arachidonoyltaurine. Biochemistry 2008, 47, 3917-3925.

188. Alhouayek, M.; Muccioli, G.G. COX-2-derived endocannabinoid metabolites as novel inflammatory mediators. Trends Pharmacol. Sci. 2014, 35, 284-292.

189. Woodward, D.F.; Carling, R.W.; Cornell, C.L.; Fliri, H.G.; Martos, J.L.; Pettit, S.N.; Liang, Y.; Wang, J.W. The pharmacology and therapeutic relevance of endocannabinoid derived cyclo-oxygenase (COX)-2 products. Pharmacol. Ther. 2008, 120, 71-80.

190. Duggan, K.C.; Hermanson, D.J.; Musee, J.; Prusakiewicz, J.J.; Scheib, J.L.; Carter, B.D.; Banerjee, S.; Oates, J.A.; Marnett, L.J. (R)-Profens are substrate-selective inhibitors of endocannabinoid oxygenation by COX-2. Nat. Chem. Biol. 2011, 7, 803-809.

191. Prusakiewicz, J.J.; Duggan, K.C.; Rouzer, C.A.; Marnett, L.J. Differential sensitivity and mechanism of inhibition of COX-2 oxygenation of arachidonic acid and 2-arachidonoylglycerol by ibuprofen and mefenamic acid. Biochemistry 2009, 48, 7353-7355.

192. Gatta, L.; Piscitelli, F.; Giordano, C.; Boccella, S.; Lichtman, A.; Maione, S.; Di Marzo, V. Discovery of prostamide F $2 \alpha$ and its role in inflammatory pain and dorsal horn nociceptive neuron hyperexcitability. PLoS One 2012, 7, e31111.

193. Woodward, D.F.; Wang, J.W.; Poloso, N.J. Recent progress in prostaglandin F2 $\alpha$ ethanolamide (prostamide F2 $\alpha$ ) research and therapeutics. Pharmacol. Rev. 2013, 65, 1135-1147.

194. Snider, N.T.; Nast, J.A.; Tesmer, L.A.; Hollenberg, P.F. A cytochrome P450-derived epoxygenated metabolite of anandamide is a potent cannabinoid receptor 2-selective agonist. Mol. Pharmacol. 2009, 75, 965-972.

195. Stark, K.; Dostalek, M.; Guengerich, F.P. Expression and purification of orphan cytochrome $\mathrm{P}_{450}$ 4X1 and oxidation of anandamide. FEBS J. 2008, 275, 3706-3717.

196. Pan, B.; Wang, W.; Long, J.Z.; Sun, D.; Hillard, C.J.; Cravatt, B.F.; Liu, Q.S. Blockade of 2-arachidonoylglycerol hydrolysis by selective monoacylglycerol lipase inhibitor 4-nitrophenyl 4-(dibenzo $[d][1,3]$ dioxol-5-yl(hydroxy)methyl)piperidine-1-carboxylate (JZL184) Enhances retrograde endocannabinoid signaling. J. Pharmacol. Exp. Ther. 2009, 331, 591-597.

197. Schlosburg, J.E.; Blankman, J.L.; Long, J.Z.; Nomura, D.K.; Pan, B.; Kinsey, S.G.; Nguyen, P.T.; Ramesh, D.; Booker, L.; Burston, J.J.; et al. Chronic monoacylglycerol lipase blockade causes functional antagonism of the endocannabinoidsystem. Nat. Neurosci. 2010, 13, 1113-1119.

(C) 2014 by the authors; licensee MDPI, Basel, Switzerland. This article is an open access article distributed under the terms and conditions of the Creative Commons Attribution License (http://creativecommons.org/licenses/by/4.0/). 